\title{
Bio-DEE Synthesis and Dehydrogenation Coupling of Bio-Ethanol to Bio-Butanol over Multicomponent Mixed Metal Oxide Catalysts
}

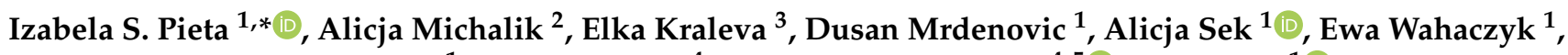 \\ Agnieszka Lewalska-Graczyk ${ }^{1}$, Mikolaj Krysa ${ }^{4}$, Anna Sroka-Bartnicka ${ }^{4,5}$ (D) Piotr Pieta ${ }^{1}$ (D), \\ Robert Nowakowski $^{1}{ }^{(D)}$, Agata Lew ${ }^{6}$ and Ewa M. Serwicka ${ }^{2}$ (D) \\ Citation: Pieta, I.S.; Michalik, A.; \\ 1 Institute of Physical Chemistry Polish Academy of Science, 01-224 Warsaw, Poland; \\ dmrdenovic@ichf.edu.pl (D.M.); alicja.sek@umcs.pl (A.S.); e.wachaczyk@ichf.edu.pl (E.W.); \\ alewalska-graczyk@ichf.edu.pl (A.L.-G.); ppieta@ichf.edu.pl (P.P.); rnowakowski@ichf.edu.pl (R.N.) \\ 2 Jerzy Haber Institute of Catalysis and Surface Chemistry PAS, Niezapominajek 8, 30-239 Krakow, Poland; \\ ncmichal@cyf-kr.edu.pl (A.M.); ncserwic@cyf-kr.edu.pl (E.M.S.) \\ 3 Leibniz-Institut für Katalyse e.V. (LIKAT Rostock), Albert-Einstein-Str. 29a, 18059 Rostock, Germany; \\ Elka.Kraleva@catalysis.de \\ 4 Department of Biopharmacy, Medical University of Lublin, Chodzki 4a, 20-093 Lublin, Poland; \\ krysamikolaj@gmail.com (M.K.); anna.sroka@umlub.pl (A.S.-B.) \\ 5 Department of Genetics and Microbiology, Maria Curie-Skłodowska University, Akademicka 19, \\ 20-033 Lublin, Poland \\ 6 Chemeko-System SP. z o.o, 54-519 Wroclaw, Poland; agata.lew@chemekosystem.pl \\ * Correspondence: ipieta@ichf.edu.pl; Tel.: +48-223-432-092
} Kraleva, E.; Mrdenovic, D.; Sek, A.; Wahaczyk, E.; Lewalska-Graczyk, A.; Krysa, M.; Sroka-Bartnicka, A.; Pieta, P.; et al. Bio-DEE Synthesis and Dehydrogenation Coupling of Bio-Ethanol to Bio-Butanol over Multicomponent Mixed Metal Oxide Catalysts. Catalysts 2021, 11, 660. https://doi.org/10.3390/catal11060660

Academic Editors: Irina L. Simakova and Dmitry Yu. Murzin

Received: 30 April 2021

Accepted: 19 May 2021

Published: 22 May 2021

Publisher's Note: MDPI stays neutra with regard to jurisdictional claims in published maps and institutional affiliations.

Copyright: (C) 2021 by the authors. Licensee MDPI, Basel, Switzerland. This article is an open access article distributed under the terms and conditions of the Creative Commons Attribution (CC BY) license (https:// creativecommons.org/licenses/by/ $4.0 /)$

\begin{abstract}
Within the Waste2Fuel project, innovative, high-performance, and cost-effective fuel production methods from municipal solid wastes (MSWs) are sought for application as energy carriers or direct drop-in fuels/chemicals in the near-future low-carbon power generation systems and internal combustion engines. Among the studied energy vectors, $C_{1}-C_{2}$ alcohols and ethers are mainly addressed. This study presents a potential bio-derived ethanol oxidative coupling in the gas phase in multicomponent systems derived from hydrotalcite-containing precursors. The reaction of alcohol coupling to ethers has great importance due to their uses in different fields. The samples have been synthesized by the co-precipitation method via layered double hydroxide (LDH) material synthesis, with a controlled $\mathrm{pH}$, where the $\mathrm{M}(\mathrm{II}) / \mathrm{M}(\mathrm{III}) \approx 0.35$. The chemical composition and topology of the sample surface play essential roles in catalyst activity and product distribution. The multiple redox couples $\mathrm{Ni}^{2+} / \mathrm{Ni}^{3+}, \mathrm{Cr}^{2+} / \mathrm{Cr}^{3+}, \mathrm{Mn}^{2+} / \mathrm{Mn}^{3+}$, and the oxygen-vacant sites were considered as the main active sites. The introduction of $\mathrm{Cr}\left(\mathrm{Cr}^{3+} / \mathrm{Cr}^{4+}\right)$ and $\mathrm{Mn}\left(\mathrm{Mn}^{3+} / \mathrm{Mn}^{4+}\right)$ into the crystal lattice could enhance the number of oxygen vacancies and affect the acid/base properties of derived mixed oxides, which are considered as crucial parameters for process selectivity towards bio-DEE and bio-butanol, preventing long $\mathrm{CH}$ chain formation and coke deposition at the same time.
\end{abstract}

Keywords: layered double hydroxide; hydrotalcite-derived mixed oxides; bio-ethanol; n-butanol; diethyl ether; aldol condensation

\section{Introduction}

Thirty years ago, in 1990, the first report of the Intergovernmental Panel on Climate Change (IPCC) was released, aiming to (1) summarize existing scientific knowledge on anthropogenic climate change, (2) assess the impact of climate change on humanity, and (3) identify solutions to the problem [1]. The world's energy resources and consumption have been determined in terms of greenhouse gas (GHG) emissions by applying predictive models. Currently, it is expected that advanced biofuels and alternative fuels will play an increasingly pivotal role in the gradual substitution of fossil fuels with fuels of renewable 
origins, transport decarbonization, and the diversification of energy sources, according to European Union legislation on sustainable growth [2-6]. Fuel demand and GHG challenges will most likely require the use of fuel mixtures, which can be derived from a large variety of primary energy sources, with renewable ones taking priority [7-10]. The advantages of biomass-derived fuels, such as biogas, bio-methanol, and bio-ethanol, as alternatives have been highlighted $[6,11]$. There is a broad agreement that all sustainable fuels will need to eliminate the carbon footprint [12] and fully meet the expected demand to also be used among others as feedstocks in various chemical processes and fine chemical synthesis to valuable products $[13,14]$. Among versatile and vital resources, biomass and wastes (i.e., municipal solid wastes, MSWs) receive continuously increasing attention as a promising feedstock (carbon source) for chemical and fuel production [12,15-17].

Bio-ethanol, obtained from polysaccharide biomass, is an attractive product for use as chemicals and biofuels [18-20]. It is used as an alternative energy source for substituting gasoline. Bio-ethanol is critical as an intermediate product in the new chemical industry based on renewables [21]. Current bio-ethanol production is predominantly based on corn and sugarcane [17]. During the last decade, ethanol production from abundant and inexpensive lignocellulose gained increasing attention. Moreover, several technical improvements extend the possibilities for commercial ethanol production, e.g., improved enzymes to convert starch to sugars (hydrolysis), enhanced bacteria (fermentation), and water separation methods. From this perspective, ethanol can be considered one of the most promising biobased chemicals, mainly due to its broad potential as a feedstock for multiple processes and its established high-volume production $[12,15,16]$. Bio-ethanol has an advantage compared to other biomass feedstocks, such as lignin, cellulose, hemicellulose, and fatty acids: it can be directly converted, in one-pot processes, into "drop-in" chemicals [22]. Apart from that, bio-ethanol can be used to obtain some of the same building block chemicals currently obtained from petroleum (e.g., ethylene, 1,3-butadiene, propylene, and higher hydrocarbons) as well as for the production of oxygenated molecules (e.g., 1-butanol, ethyl acetate, acetaldehyde, and acetic acid) [23].

Chemicals from ethanol reactions can be broadly grouped into two types. Those that do not form C-C bonds (non-C-C coupling products, e.g., formaldehyde, methyl acetate, etc.) and those that form $\mathrm{C}-\mathrm{C}$ bonds (C-C coupling products, e.g., $\mathrm{C}_{3+}$ alcohols, aldehydes, esters, etc.) [24-26]. The C-C coupling products are of particular interest as they possess higher energy contents than ethanol and can be hydrogenated to $\mathrm{C}_{3+}$ alcohols. These products (e.g., n-propanol, butanols) are considered as more desirable drop-in additives compared to ethanol due to their superior chemical (e.g., less hygroscopic, higher energy content) and fuel characteristics (e.g., higher octane numbers) $[27,28]$. Moreover, it has been shown that ethanol coupling offers an economical and sustainable route for $n$-butanol production [29]. In addition to the drop-in chemicals, other commodity chemicals can be industrially produced from ethanol $[17,22]$. For example, Davy Technologies has developed a one-pot process for the partial dehydrogenation of bio-ethanol into ethyl acetate [30], using, i.e., copper supported on silica catalyst, with a production of 50,000 tons per year in South Africa plant [31].

The hydrotalcite-based materials have been reported to show good catalytic activity in various reactions, such as biogas [32], coke, or methane reforming, as well as sorption capacity, stability, and easy regeneration by temperature or pressure swing [33-47]. Hydrotalcites (HTs) are naturally occurring layered double hydroxides (LDHs). The mineral hydrotalcite itself is a magnesium-aluminum hydroxycarbonate with the general formula $\left[\mathrm{Mg}_{6} \mathrm{Al}_{2}(\mathrm{OH})_{16}\right] \mathrm{CO}_{3}{ }^{*} 4 \mathrm{H}_{2} \mathrm{O}[38,40,48]$. The $\mathrm{HT}$ family includes many isost $\times \times$ ructural and polytype forms [38-40,48,49]. Their properties can be tailored through cation and anion exchange in the precursor framework [49-51]. The possibility of modifying the cations or their ratios and the interlaminar anion makes these materials a very versatile system with desirable catalytic properties. The adjustment of the acidic or basic properties of LDHs or mixed oxides that are generated by calcination at high temperatures has recently been studied [38-51]. 
Acid-base properties in $\mathrm{Mg}-\mathrm{Al}$ mixed oxides, generally known to be crucial for catalytic activity and selectivity, strongly depend on their chemical compositions and preparation procedures $[48,52]$. Although much is now known about the properties of hydrotalcite-based materials, the composition and structure of the active sites and reaction mechanism of ethanol coupling to butanol have not been clearly defined.

In this work, the development of heterogeneous catalysts for the conversion of ethanol into commodity chemicals is discussed. Ni-based catalysts obtained from hydrotalcitecontaining precursors were synthesized and studied. The effect of different divalent and triand four-valent cations $\left(\mathrm{Ca}^{2+}, \mathrm{Mg}^{2+}, \mathrm{Ni}^{2+} / \mathrm{Ni}^{3+}, \mathrm{Cr}^{2+} / \mathrm{Cr}^{3+} / \mathrm{Cr}^{4+}, \mathrm{Mn}^{2+} / \mathrm{Mn}^{3+} / \mathrm{Mn}^{4+}, \mathrm{Al}^{3+}\right.$, $\mathrm{Zr}^{4+}$ ) presence in the HTs precursor-containing framework on the performance of the mixed oxide catalysts was investigated. This work aims to elucidate the site requirements for ethanol coupling to butanol and diethyl ether (DEE) over the hydrotalcite-based materials and the mechanism by which this process occurs.

\section{Results}

\subsection{Catalyst Characterization}

The chemical compositions of the mixed oxide active phases are shown in Table 1. These data confirm that the obtained compositions of all WP samples are close to the intended ones based on the ratios of the key elements of the $\mathrm{Al}$ component.

Table 1. Catalysts and atomic ratios of structural elements relative to $\mathrm{Al}$ content.

\begin{tabular}{|c|c|c|c|c|c|c|c|}
\hline \multirow{2}{*}{ Catalyst } & \multicolumn{7}{|c|}{ Atomic Ratios from Synthesis (Measured by EDS) } \\
\hline & $\mathrm{Ni}$ & $\mathrm{Mg}$ & $\mathrm{Ca}$ & Mn & $\mathrm{Cr}$ & $\mathrm{Zr}$ & Al \\
\hline WP-1: $\mathrm{Ni}_{0.35} \mathrm{Al}-\mathrm{CO}_{3}$ & $\begin{array}{c}0.35 \\
(0.44)\end{array}$ & - & - & - & - & - & $1.00(1.0)$ \\
\hline WP-2: $\mathrm{Ni}_{0.35} \mathrm{Mg}_{0.13} \mathrm{Al}-\mathrm{CO}_{3}$ & $\begin{array}{c}0.35 \\
(0.51)\end{array}$ & $\begin{array}{c}0.13 \\
(0.15)\end{array}$ & - & - & - & - & $1.00(1.0)$ \\
\hline $\begin{array}{l}\text { WP-3: } \mathrm{Ni}_{0.35} \mathrm{Mg}_{0.13} \mathrm{Mn}_{0.0018} \\
\mathrm{Cr}_{0.0017} \mathrm{Zr}_{0.0054} \mathrm{Al}-\mathrm{CO}_{3}\end{array}$ & $\begin{array}{c}0.35 \\
(0.41)\end{array}$ & $\begin{array}{c}0.13 \\
(0.22)\end{array}$ & - & $\begin{array}{c}0.0018 \\
(0.0098)\end{array}$ & $\begin{array}{c}0.0017 \\
(0.0088)\end{array}$ & $\begin{array}{c}0.0054 \\
(0.0062)\end{array}$ & $1.00(1.0)$ \\
\hline WP-4: $\mathrm{Ni}_{0.35} \mathrm{Ca}_{0.13} \mathrm{Al}-\mathrm{CO}_{3}$ & $\begin{array}{c}0.35 \\
(0.43)\end{array}$ & - & $\begin{array}{c}0.13 \\
(0.14)\end{array}$ & - & - & - & $1.00(1.0)$ \\
\hline $\begin{array}{l}\text { WP-5: } \mathrm{Ni}_{0.35} \mathrm{Ca}_{0.13} \mathrm{Mn}_{0.0018} \\
\mathrm{Cr}_{0.0017} \mathrm{Zr}_{0.0054} \mathrm{Al}-\mathrm{CO}_{3}\end{array}$ & $\begin{array}{c}0.35 \\
(0.41)\end{array}$ & - & $\begin{array}{c}0.13 \\
(0.22)\end{array}$ & $\begin{array}{c}0.0018 \\
(0.0098)\end{array}$ & $\begin{array}{c}0.0017 \\
(0.0088)\end{array}$ & $\begin{array}{c}0.0054 \\
(0.0062)\end{array}$ & $1.00(1.0)$ \\
\hline
\end{tabular}

Figure 1 shows the XRD patterns of active phase precursors obtained by the standard co-precipitation method (Figure 1A) as well as calcined and spent catalyst samples (Figure 1B,C, respectively).

Pristine (only dried) WP1 hydrotalcite-like materials showed broad reflections attributable to a crystalline hydrotalcite phase, with indexing following the previously reported data (reflections at $2 \theta$ equal to $11^{\circ}, 23^{\circ}$, and $35^{\circ}$; JCPDS 22-0452) $[53,54]$. These data suggest the isomorphic substitution of $\mathrm{Mg}^{2+}$ by $\mathrm{Ni}^{2+}$ in hydrotalcite brucite-like layers, which is in agreement with similarity in the effective ionic radius of those two components (Table 2) $[55,56]$. However, it is worth noting that the peaks related to the hydrotalcite phase are broad, and their intensity decreased with increasing content of the different divalent and tri- and four-valent cations $\left(\mathrm{Ca}^{2+}, \mathrm{Mg}^{2+}, \mathrm{Ni}^{2+} / \mathrm{Ni}^{3+}, \mathrm{Cr}^{2+} / \mathrm{Cr}^{3+} / \mathrm{Cr}^{4+}\right.$, $\left.\mathrm{Mn}^{2+} / \mathrm{Mn}^{3+} / \mathrm{Mn}^{4+}, \mathrm{Al}^{3+}, \mathrm{Zr}^{4+}\right)$. This can indicate indicating a more disordered structure, changes in layer-spacing or a decrease in crystallinity [55-58]. Additionally, for Mgcontaining samples, traces of crystalline $\mathrm{Al}(\mathrm{OH})_{3}$ (bayerite, JCPDS: 21-1307) phase were evident. The phase was present due to the excess of aluminum ions in relation to the hydrotalcite structure requirement (in the natural hydrotalcite $\mathrm{M}^{2+} / \mathrm{M}^{3+}=3$, and in the formulations $\left.\mathrm{M}^{2+} / \mathrm{M}^{3+} \approx 0.35\right)$. 

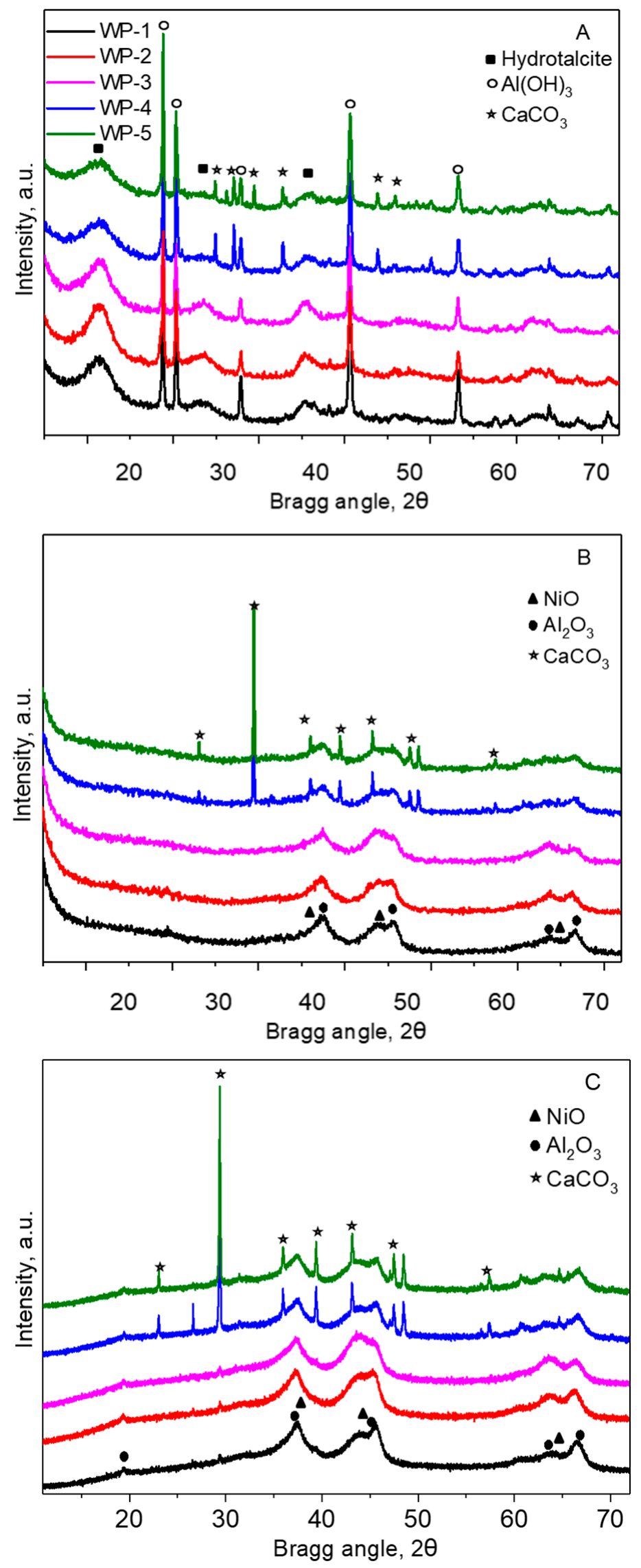

Figure 1. XRD patterns of the (A) as prepared, (B) calcined, and (C) after-reaction samples. 
Table 2. Ionic radii of the selected elements [56].

\begin{tabular}{ccc}
\hline \multirow{2}{*}{ Element } & \multicolumn{2}{c}{ Ionic Radii, pm (Ion Coordination) } \\
\cline { 2 - 3 } & Crystal & Effective \\
\hline $\mathrm{Mg}$ & $86(+2)$ & $72(+2)$ \\
$\mathrm{Ca}$ & $114(+2)$ & $100(+2)$ \\
$\mathrm{Al}$ & $67.5(+2)$ & $53.5(+2)$ \\
$\mathrm{Ni}$ & $83(+2), 70(+3)$ & $69(+2), 56(+3)$ \\
$\mathrm{Cr}$ & $87(+2), 75.5(+3), 69(+4)$ & $73(+2), 61.5(+3), 55(+4)$ \\
$\mathrm{Zr}$ & $86(+4)$ & $72(+4)$ \\
$\mathrm{Mn}$ & $81(+2), 72(+3), 67(+4)$ & $67(+2), 58(+3), 53(+4)$ \\
\hline
\end{tabular}

The formation of bimetallic solids between $\mathrm{Ni}$ and $\mathrm{Al}$ can be explained by the insertion of $\mathrm{Al}^{3+}$ ions $(69 \mathrm{pm})$ in the $\mathrm{NiO}$ crystal lattice, which, due to the lower ionic radius of $\mathrm{Al}^{3+}$, leads to the decrease in the dimensions of $\mathrm{NiO}$ cubic cells. This insertion is allowed as the size of the $\mathrm{Al}^{3+}$ does not differ by more than $15 \%$ from that of the $\mathrm{Ni}^{2+}(72 \mathrm{pm})$, and it crystallizes in the cubic system in the form of transition alumina that can be formed by calcination. Moreover, it has an electronegativity close to that of nickel, which complies with three of the Hume-Rothery rules. For Ca-containing samples, the presence of $\mathrm{CaCO}_{3}$ (vaterite modification) was observed, consistent with the previously reported data for calcium carbonate samples [57,58]. Additionally, intensity decrease and broadening of XRD pattern reflexes were observed (Figure 1A), suggesting incompatibility between the charge $\left(\mathrm{Cr}^{4+}, \mathrm{Mn}^{4+}, \mathrm{Zr}^{4+}\right)$ and the ionic radius of selected elements (Table 2) of the dopant and the crystal structure of the brucite layer in HT-like material [51]. The HT-like phase structure collapsed for samples calcined at $823 \mathrm{~K}$, and different phases were detected in the XRD diffraction patterns (Figure 1B). The reflections characteristic of the periclase-like structure of mixed oxides (reflections at $2 \theta$ equal to $37^{\circ}, 43.5^{\circ}, 63^{\circ}$ ) were the most intense [55]. Some overlapping signals related to $\mathrm{NiO}$ (JCPDS 65-5745) and $\mathrm{Al}_{2} \mathrm{O}_{3}$ (JCPDS 04-0880) were also observed. In the samples containing calcium, $\mathrm{CaCO}_{3}$ phase transformation to calcite was evidenced with sharp reflections located at $2 \theta$ equal to $37^{\circ}, 43.5^{\circ}, 63^{\circ}$. This result shows that the calcination performed at $823 \mathrm{~K}$ was sufficient to transform the hydrotalcite and bayerite phases into the corresponding oxide forms but was too low to cause the $\mathrm{CaCO}_{3}$ decomposition. All detected phases in calcined samples were present in samples after reaction (Figure $1 \mathrm{C}$ ), suggesting good structure stability of the samples. The BET area $\left(\mathrm{A}_{\mathrm{BET}}\right)$ measured for the calcined samples stayed roughly constant at around $210 \mathrm{~m}^{2} / \mathrm{g}$ in both types of samples (Mg-containing WP-1, WP-2, and WP-3) or Ca-containing ones (WP-4, WP-5).

Figure 2 shows SEM and TEM images of the calcined (WP-1-WP-5) and after reaction (WP-1AR-WP-5AR) samples. All catalysts obtained from hydrotalcite-like precursors were composed of plate-like particles (Figure 2, WP-1-WP-5). The sample morphology was not changed, comparing both Mg-containing or Ca-containing samples to the pristine WP-1 sample. Moreover, this morphology has been preserved in all samples after reaction (Figure 2, WP-1AR-WP-5AR). TEM images of calcined samples (WP-1'-WP-5'), shown in Figure 2, reveal some differences in the microstructures of prepared catalysts. In all samples, the active mixed oxide phase particles are visible as black and / or dark grey grains, dispersed among the amorphous phase. In all $\mathrm{Cr}-, \mathrm{Mn}$-, and $\mathrm{Zr}$-doped catalysts obtained from HT-like precursors, the calcined, mostly Ni-metal-based active phase forms oxide particles stayed in the range 5-6 nm. 


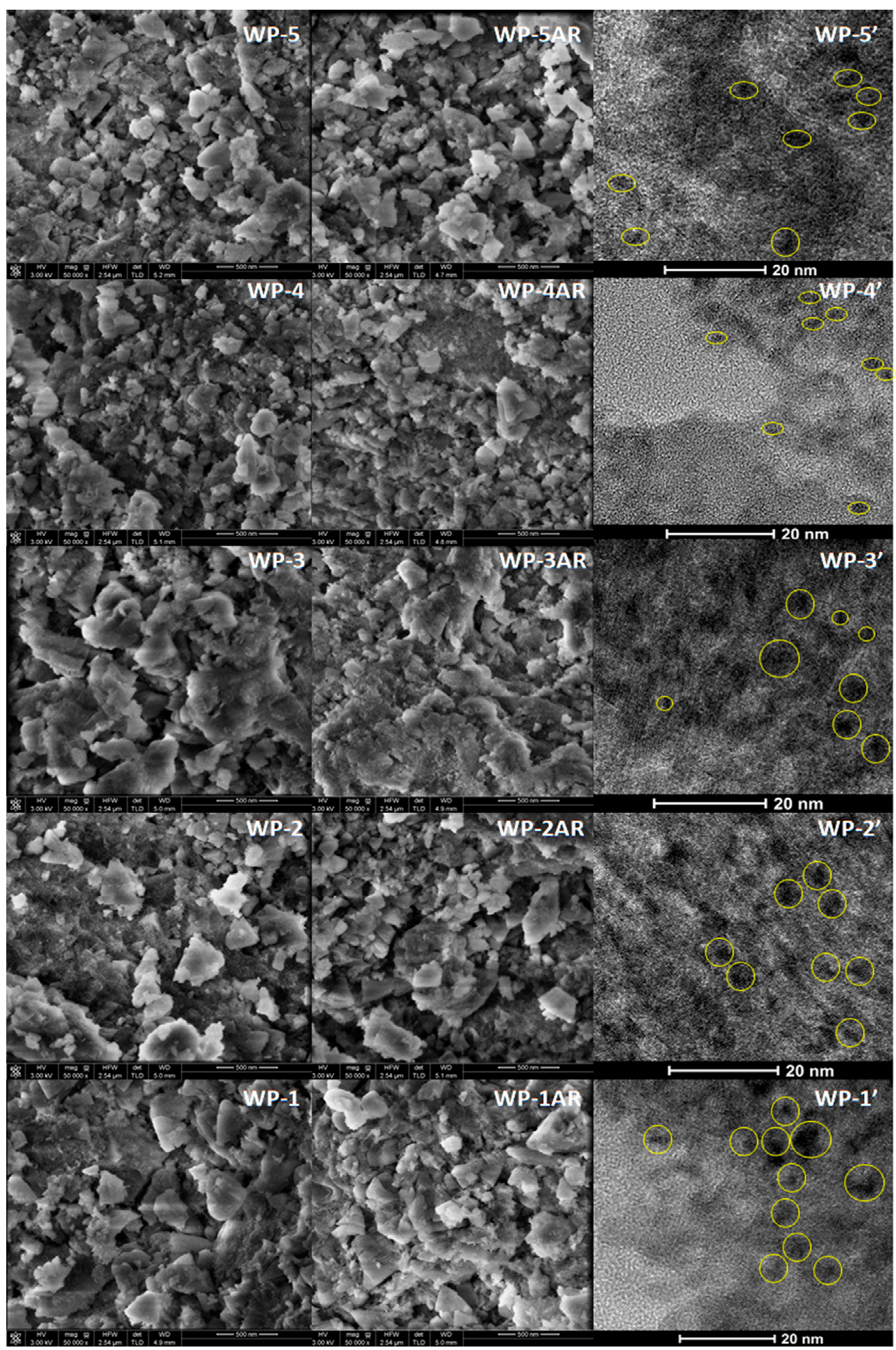

Figure 2. SEM images of the calcined catalysts WP-1-WP-5 with corresponding TEM images of WP-1'-WP-5'; and SEM images of the spent catalysts WP-1AR-WP-5AR.

The DRIFT spectra of calcined samples are shown in Figure 3. 


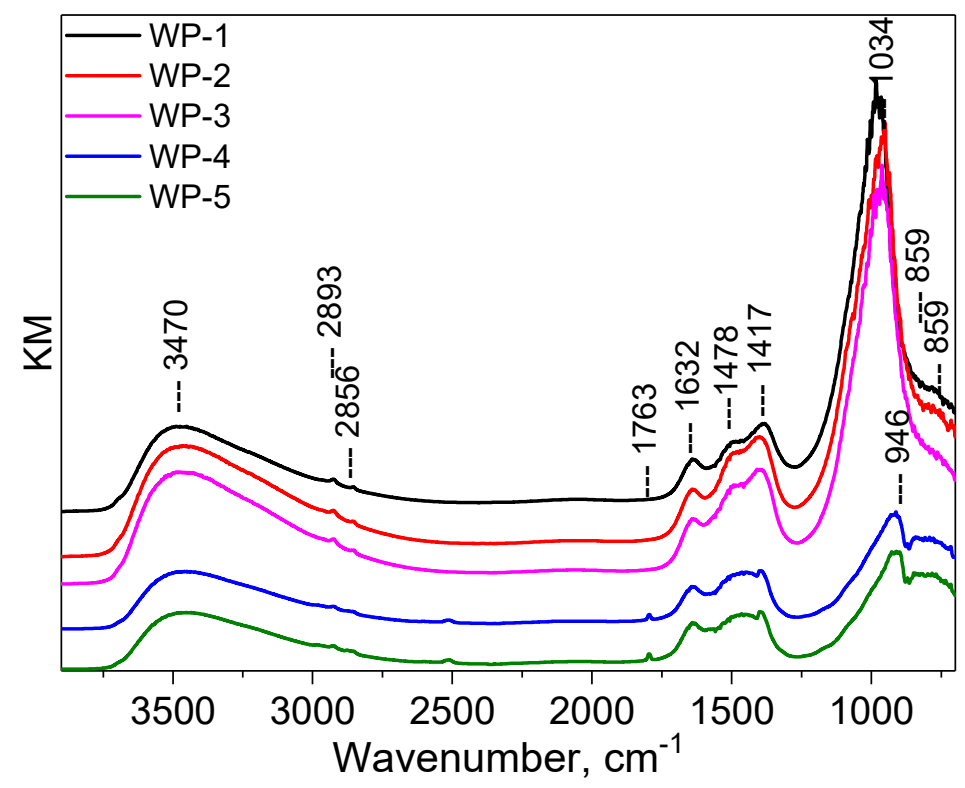

Figure 3. DRIFT spectra of the calcined WP catalysts.

The spectrum recorded for WP-1 shows three broad complex absorptions with maxima located at 700-1200, 1250-1750, and ca. $3500 \mathrm{~cm}^{-1}$, in accordance with previous studies $[33,55,59,60]$. The broad band at $3470 \mathrm{~cm}^{-1}$ was ascribed to the $\mathrm{OH}$ stretching mode $v(\mathrm{OH})^{-}$of structural hydroxyl groups. The corresponding $\mathrm{H}-\mathrm{O}-\mathrm{H}$ bending mode of physisorbed water was evidenced at $1632 \mathrm{~cm}^{-1}$. The band at $1763 \mathrm{~cm}^{-1}$ corresponds to the presence of some interlayer water. The appearance of this vibration in the spectra is most likely explained by the "memory effect" of the calcined powder sample or incomplete decomposition of the layered structure during calcination $[55,59,60]$. The bands in the $700-1200$ and $1250-1750 \mathrm{~cm}^{-1}$ spectral regions are characteristic of carbonate vibrations. For all HT-derived samples (WP-1-WP-5), the recorded spectra were similar and presented the most intense band, located at $1034 \mathrm{~cm}^{-1}$. According to the previous research, this peak can be ascribed to the $v 1$ mode of carbonate [61]. Usually, this mode stays IR-inactive due to the symmetry rules. However, in the interlayer, the $\mathrm{D}_{3 \mathrm{~h}}$ symmetry of free carbonate is lowered to $C_{3 v}$ or $C_{2 v}$, and it becomes activated. For WP-4 and WP-5 samples, displacement and splitting of this band were observed, which can be related to the calcite presence, where the local symmetry of carbonate was $\mathrm{D}_{3}$ [61]. These results are in good agreement with the XRD measurement, where the presence of calcite has been evidenced for Ca-containing samples (WP-4 and -5). The bands recorded below $1000 \mathrm{~cm}^{-1}$ can be due to the carbonate (ca. $850 \mathrm{~cm}^{-1}$ ) and $\mathrm{M}-\mathrm{OH}$ modes. Moreover, these features are also typical of the spinel structure and can be related mainly to the formation of $\gamma-\mathrm{Al}_{2} \mathrm{O}_{3}$ and $(\mathrm{Mg} / \mathrm{Mn} / \mathrm{Cr} / \mathrm{Zr}) \mathrm{Al}_{2} \mathrm{O}_{4}$, as the bands at low wavenumbers (usually at 700 and $570 \mathrm{~cm}^{-1}$ ) are assigned to the so-called $v_{1}$ and $v_{2}$ vibrational mode of isolated tetrahedra, i.e., [ $\left.\mathrm{AlO}_{4}\right]$ and octahedra, i.e., $\left[\mathrm{AlO}_{6}\right]$, respectively $[55,60]$.

The Raman spectra of the calcined WP-1-WP-5 samples before and after the reaction are presented in Figure 4. A broad signal around $551 \mathrm{~cm}^{-1}$ was also observed for all the materials. This signal was related to octahedral $\mathrm{Ni}^{2+}$ species. Usually, the Raman spectra of nickel oxide are reported to possess five bands that originate from the optical vibrations produced by one phonon (1P) of the transverse optical (TO-440 $\mathrm{cm}^{-1}$ ) and longitudinal optical (LO-560 $\mathrm{cm}^{-1}$ ) and by two phonons (2P). As a result of the TO+TO $\mathrm{TO}+\mathrm{LO}$ and $\mathrm{LO}+\mathrm{LO}$ coupling, three scatterings were further observed at 730, 930, and $1080 \mathrm{~cm}^{-1}$ [62-64]. The Raman spectra of all the calcined WP samples mainly displayed the band originating from the $1 \mathrm{P}$ scattering at $551 \mathrm{~cm}^{-1}$, whereas bands related to the $2 \mathrm{P}$ coupling were not identified. This band is considered as characteristic of nickel oxide with alterations in its crystalline structure, which may be due to vacancies created by the 
non-stoichiometric $\mathrm{Ni}_{1-\mathrm{x}} \mathrm{O}$ oxide or the $\mathrm{Ni}^{3+}$ presence in the structure [64]. The presence of smaller $\mathrm{Al}^{3+}$ ions in the $\mathrm{NiO}$ lattice may cause the formation of crystalline defects and vacancies, favoring the $1 \mathrm{P}$ interaction. It is noteworthy that, when traces of $\mathrm{Mn}, \mathrm{Cr}$, and $\mathrm{Zr}$ are present in the structure, the band at $551 \mathrm{~cm}^{-1}$ is wider, and blue shifted. This can be explained by the formation of more defects and vacancies by dopant ions and/or by the band coincidence with the lattice vibration of the hydroxyl layers of these metals [62-64]. In Figure 4B, the Raman spectra of the WP-X samples after the reaction are shown. It was noticed that signals associated with the carbon are intense, shielding the metal signals. The Raman spectra showed two characteristic peaks at 1585 and $1350 \mathrm{~cm}^{-1}$ related to the $\mathrm{G}$ and $\mathrm{D}$ bands. The $\mathrm{G}$ band corresponds to the stretching vibration between the $\mathrm{C}-\mathrm{C}$ bonds along the longitudinal axis of the graphite plane. In contrast, the D band refers to association with the presence of amorphous carbon, disordered crystal structure, or crystal defects $[65,66]$. The bands were deconvoluted as described previously; however, other bands $\left(D_{2}, D_{3}, D_{4}\right)$ were not detected [67]. The graphitic index $\left(I_{G}\right)$ of the samples was calculated from the deconvolution of the signals, and the value for all the materials was around $25 \%$. The collected spectra revealed that the carbon formation during the carried reaction was the highest for the WP-1 sample. In general, the Mg-containing catalysts contained more coke after the coupling reaction, and they were more active than Ca-containing catalysts (Table 3 ).

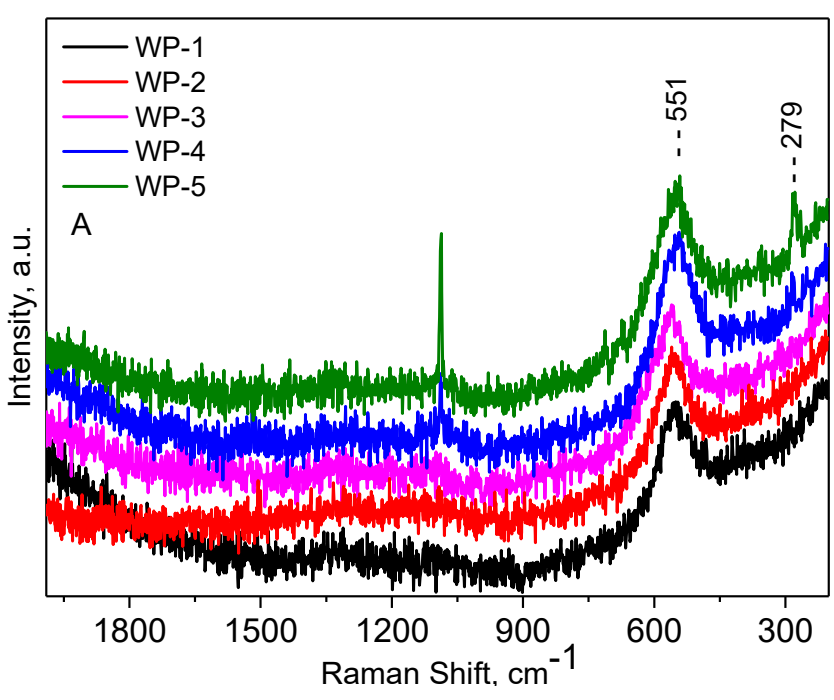

(A)

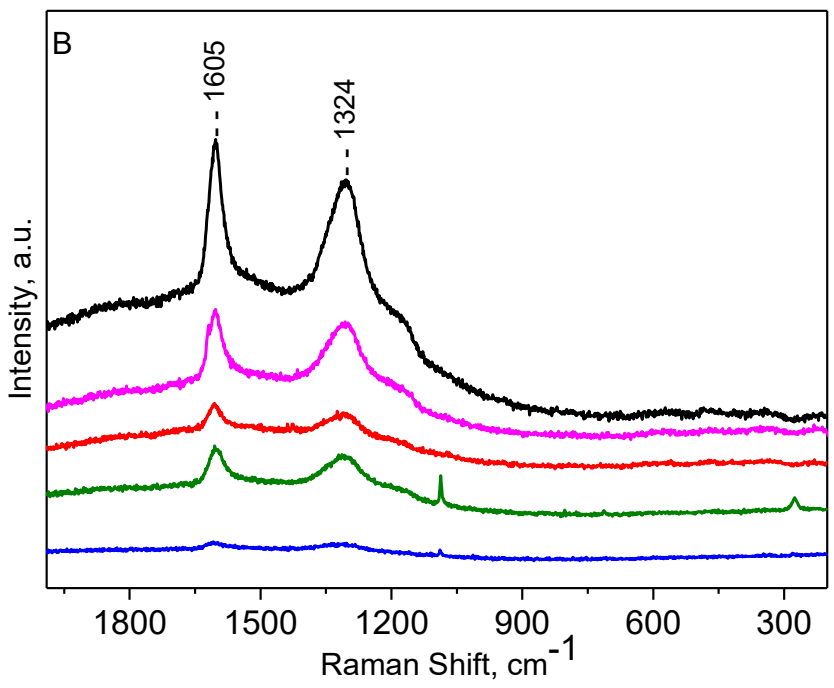

(B)

Figure 4. Raman spectra of the (A) calcined and (B) after-reaction WP catalysts.

Table 3. The physicochemical characterization and activity data.

\begin{tabular}{|c|c|c|c|c|c|c|}
\hline \multirow{2}{*}{ Catalyst } & \multicolumn{6}{|c|}{ Selectivity, mol\% } \\
\hline & $A_{B E T}, m^{2} g^{-1}$ & Conv, $\%$ & Ethyl Ether & n-BuOH & Others $^{1}$ & C Balance, $\mathrm{mol} \%$ \\
\hline WP-1: $\mathrm{Ni}_{0.35} \mathrm{Al}-\mathrm{CO}_{3}$ & 223 & 97.5 & 32.1 & 16.3 & 51.7 & 93.4 \\
\hline WP-2: $\mathrm{Ni}_{0.35} \mathrm{Mg}_{0.13} \mathrm{Al}-\mathrm{CO}_{3}$ & 216 & 9.5 & 26.1 & 45.7 & 28.2 & 95.1 \\
\hline $\begin{array}{l}\text { WP-3: } \mathrm{Ni}_{0.35} \mathrm{Mg}_{0.13} \mathrm{Mn}_{0.0018} \\
\mathrm{Cr}_{0.0017} \mathrm{Zr}_{0.0054} \mathrm{Al}-\mathrm{CO}_{3}\end{array}$ & 230 & 12.8 & 53.7 & 31.1 & 15.2 & 94.2 \\
\hline WP-4: $\mathrm{Ni}_{0.35} \mathrm{Ca}_{0.13} \mathrm{Al}-\mathrm{CO}_{3}$ & 207 & 5.1 & 19.9 & 34.7 & 45.4 & 84.1 \\
\hline $\begin{array}{l}\text { WP-5: } \mathrm{Ni}_{0.35} \mathrm{Ca}_{0.13} \mathrm{Mn}_{0.0018} \\
\mathrm{Cr}_{0.0017} \mathrm{Zr}_{0.0054} \mathrm{Al}-\mathrm{CO}_{3}\end{array}$ & 212 & 10.3 & 31.9 & 28.8 & 39.2 & 80.2 \\
\hline
\end{tabular}

${ }^{1}$ Other products include acetaldehyde, ethyl acetate, butanal, butyl acetate, ethyl butyrate, 2-ethyl-butanal, hexanal, n-hexanol, butyl butyrate, ethyl caproate, etc., and also $\mathrm{CO} / \mathrm{CO}_{2}$ (if any). 


\subsection{Catalytic Performance}

Figure 5 presents the effect of metal type content on the catalytic performance during $\mathrm{EtOH}$ coupling reactions. At the investigated reaction conditions $\left(350^{\circ} \mathrm{C}\right.$, ambient pressure; GHSV $\left.=1.19 \times 10^{5} \mathrm{~h}^{-1}\right)$, the $\mathrm{MgAl}$ catalyst had a very low alcohol conversion $(\mathrm{EtOH}$ conv. $\sim 10 \%$ ) but high C-selectivity to n-butanol and ethyl ether (>40\%). Ethanol coupling occurred in the same temperature range for all the catalysts. There are several differences in terms of activity, defined as conversion after $100 \mathrm{~min}$ and selectivity towards DEE and n-butanol (Table 3). Incorporation of $\mathrm{Ni}$ in $\mathrm{MgAlO}$ (WP-2) afforded a selectivity of $46 \%$ to nbutanol with an ethanol conversion of $15 \%$. However, the $\mathrm{NiAlCO}_{3}$ sample (WP-1) showed high ethanol conversion (97\%), but the selectivity of n-butanol and ethyl ether decreased. Indeed, for the $\mathrm{NiAlCO}_{3}$ sample, apart from the product decomposition, the products' distribution changed, suggesting C-C coupling omittance, as was given previously [11]. This is due to the well-known ability of $\mathrm{Ni}$ in the form of $\mathrm{NiO}$ to activate $\mathrm{C}-\mathrm{H}$ and $\mathrm{O}-\mathrm{H}$ bonds in alcohols to form the corresponding aldehydes and also due to the more acidic nature of the surface composition determining the reaction pathway [11].
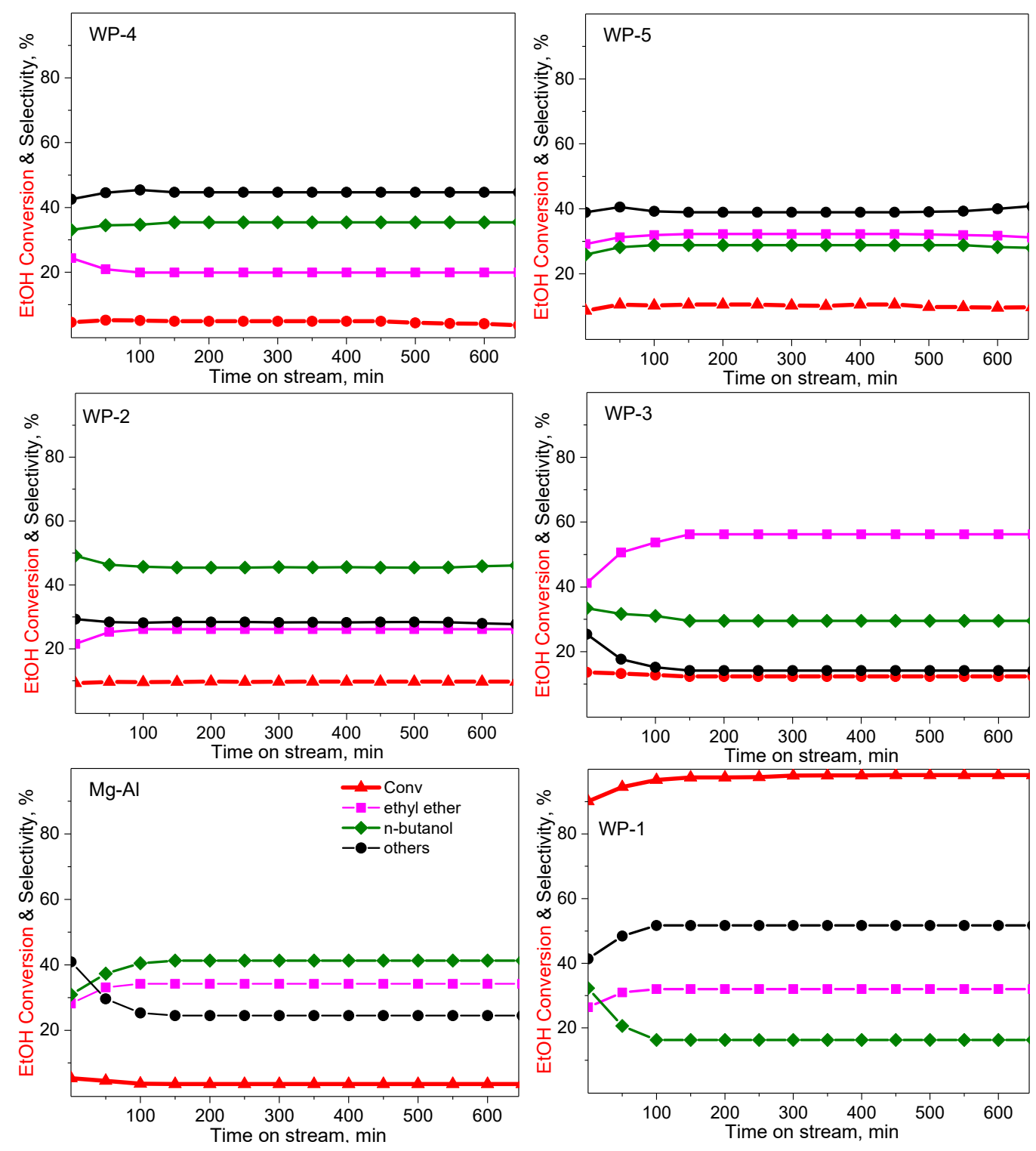

Figure 5. Ethanol conversion and stability of catalysts. Conversion and selectivity were obtained at 100 min; reaction conditions: $250{ }^{\circ} \mathrm{C}, 0.1 \mathrm{MPa}$ in steady state. (Other products include acetaldehyde, ethyl acetate, butanal, butyl acetate, ethyl butyrate, hexanal, n-hexanol, ethyl 2-ethyl butyrate, butyl butyrate, ethyl caproate, etc., and also $\mathrm{CO} / \mathrm{CO}_{2}$ (if any).) 
For the WP-3 catalyst (Mn, Cr, and Zr- modified Ni-Mg-Al mixed oxide), the highest activity was observed in terms of ethanol conversion with selectivity toward DEE approaching $60 \%$ (Figure 5). This behavior is most likely due to the introduction of $\mathrm{Mn}^{4+}$ species in the $\mathrm{Mg}$-based structure, and $\mathrm{Mg}^{2+}$ species are more active for the aldol condensation reaction. Thus, $\mathrm{n}$-butanol formation was inhibited [39]. Other studies have also reported that enhanced dehydration can be promoted instead. This is due to the interaction between $\mathrm{Mg}^{2+}$ and $\mathrm{Al}^{3+}$ that weakens the metal-support interaction as well as due to the decrease in $\mathrm{Mg} / \mathrm{Al}$ ratio $[40,41]$. The data presented in Figure 5 demonstrate that the promotor of ethanol's coupling reaction is the $\mathrm{Mg}-\mathrm{Al}$ hydrotalcite precursor, which is in agreement with the literature $[24,26,32,39,61,68]$.

Mechanistic studies of alcohol (methanol+n-propanol, ethanol) coupling reactions on mixed metal oxides $\left(\mathrm{MgAlO}_{\mathrm{x}}\right)$ have revealed that an optimum population of weak Lewis acid and strong Brønsted base-pair sites resulting from intimate contact of $\mathrm{Mg}$ and $\mathrm{Al}$ oxide phases is required for maximizing the $\mathrm{C}-\mathrm{C}$ coupling reaction rates that are not achieved with either monometallic oxides $\mathrm{MgO}$ (mostly basic), or $\mathrm{Al}_{2} \mathrm{O}_{3}$, (mostly acidic) $[24,68,69]$. DiCosimo et al. have shown that on $\mathrm{MgAlO}_{\mathrm{x}}$ mixed metal oxides (atomic $\mathrm{Mg} / \mathrm{Al}=1$ ), the maximum ethanol coupling formation rate to n-butanol coincides with the maximum density of basic sites in the catalyst $[68,69]$. In the present work, we report vapor-phase coupling reactions of ethanol on mixed metal oxides at varying metal contents aimed at maximizing the C-C coupling product for ethanol.

In the vapor phase, the main reported reaction pathways for the C-C coupling of lower alcohols to higher alcohols on multimetallic mixed oxides include several reactions, as proposed by J.J. Bravo-Suárez et al. [24].

1. Alcohol oxidation (dehydrogenation) to aldehyde:

$$
2 \mathrm{RCH}_{2} \mathrm{CH}_{2} \mathrm{OH} \leftrightarrow 2 \mathrm{RCH}_{2} \mathrm{CHO}+2 \mathrm{H}_{2}
$$

2. Aldol condensation of aldehydes with the elimination of water ( $C-C$ bond-forming) to an aldehyde:

$$
2 \mathrm{RCH}_{2} \mathrm{CHO} \leftrightarrow \mathrm{RCH}_{2} \mathrm{CH}=\mathrm{CRCHO}+\mathrm{H}_{2} \mathrm{O}
$$

3. Additionally, allylic aldehyde reduction (hydrogenation) to alcohol:

$$
\mathrm{RCH}_{2} \mathrm{CH}=\mathrm{CRCHO}+2 \mathrm{H}_{2} \leftrightarrow \mathrm{RCH}_{2} \mathrm{CH}_{2} \mathrm{CHRCH}_{2} \mathrm{OH}
$$

Other reactions that have been proposed include direct alcohol and aldehyde condensation (to C-C coupled intermediate species), hydroxy aldehyde keto-aldol interconversion, reverse aldol coupling (to keto form), esterification reactions from aldehydes and surface alkoxides, and ethanol decarbonylating (decomposition).

At the reaction conditions of our study, a wide range of different $\mathrm{EtOH}$ reaction products were observed that can be broadly grouped as: (1) C-C coupling (butanol) and dehydration (ethyl ether); (2) non-C-C coupling (e.g., $\mathrm{H}_{2} \mathrm{CO}, \mathrm{HAc}, \mathrm{HCOOCH}_{3}, \mathrm{MeOAc}$ ); and (3) decomposition (e.g., $\mathrm{CO}_{\mathrm{x}}$ ) products.

During the coupling reaction, the water was formed, but the water's presence does not harm the catalysts' structures and morphologies, evidenced by XRD (Figure 1c) and SEM (Figure 2). All catalysts preserve a mixed oxide structure. The water could remove the coke by gasification; however, for these catalysts, this route apparently did not occur with a high conversion level at the temperatures used [42].

The direct transformation of ethanol into 1-butanol is described as being catalyzed by solid bases [70]. For such catalysts, mechanistic studies have shown that ethanol dimerization is the preferred mechanism, which is usually supported by the fact that expected reaction intermediates are detected [71,72]. In general, two alternative mechanisms have been proposed for alcohol coupling, namely, a Guerbet reaction or a direct condensation mechanism (Figure 6) [71,72]. In the Guerbet reaction, the C-C formation occurs via aldol condensation. This reaction includes dehydrogenation of ethanol to an aldehyde (often 
identified as the rate-limiting step), followed by aldol-type condensation of aldehyde and transfer hydrogenation (TH) of polarized substrates [73,74]. Most likely, for studied WP-X catalysts, both $\mathrm{H}_{2}$ and produced $\mathrm{H}_{2} \mathrm{O}$ can act as hydrogen donors, as suggested earlier [73]. In the second mechanism, i.e., direct condensation, the first activation of the $\beta-\mathrm{H}$ of ethanol molecule is followed by the condensation with another ethanol via dehydration [74]. Thus, dual functionality of catalytic systems is required to provide desirable Guerbet conversion and selectivity, where one component is active in ethanol dehydrogenation and support or/and the second component shapes the acetaldehyde aldolization selectivity.

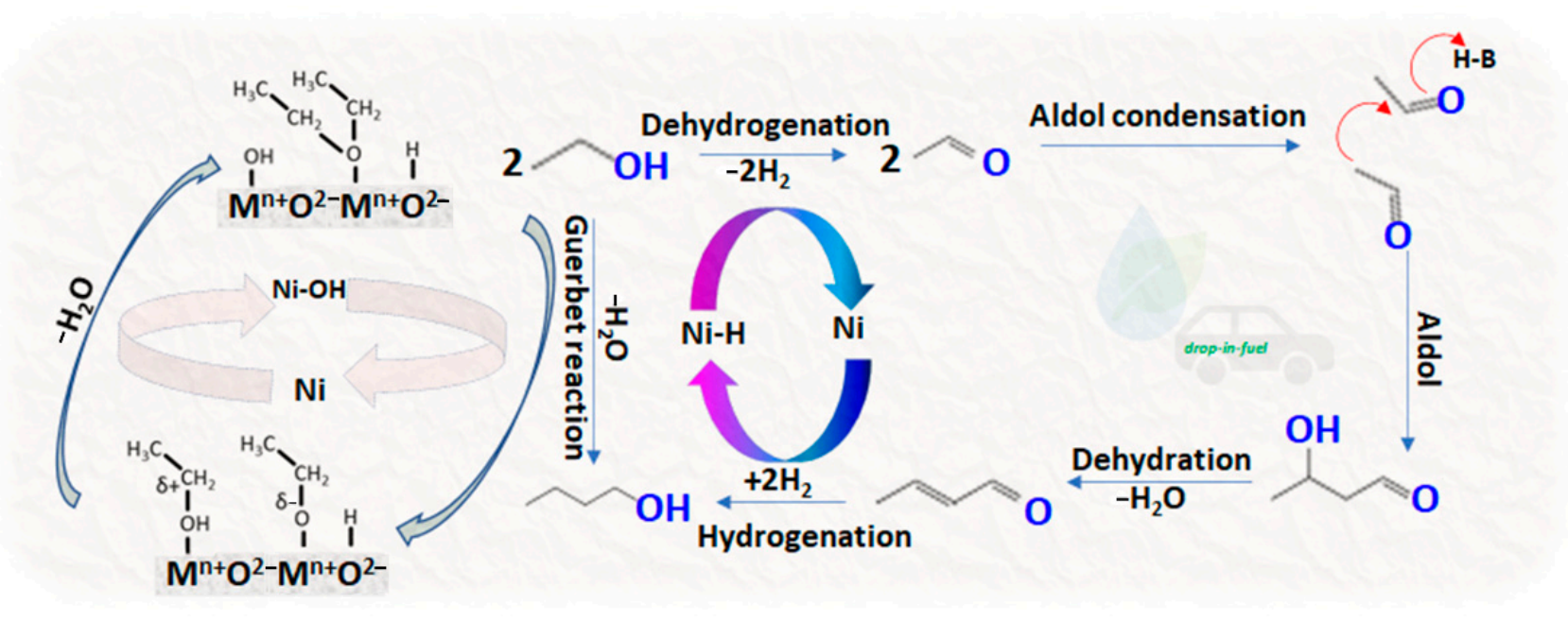

Figure 6. Mechanism of ethanol coupling with the proposed pathway of bimolecular dehydration to DEE. Based on [71,72].

Until now, various transition metals have been reported to enhance ethanol dehydrogenation, aiming to improve ethanol conversion under mild conditions [72,74]. Incorporation of $\mathrm{Ni}$ to $\mathrm{LDH}$-derived catalysts showed promising activity with high selectivities related to the acid-base site modification of WP-X catalysts' surfaces. In the Ag-supported MgAl-LDO catalyst, the basic sites promote the adsorption and subsequent dehydrogenation of ethanol on uniformly dispersed Ag particles [74]. Thus, the acid-base cooperation was ascribed to promote the $\mathrm{C}-\mathrm{C}$ bond formation of dehydrogenated intermediate via aldol condensation. In the case of investigated WP-X, Ni most likely acts as a hydrogentransfer component. Simultaneously, the presence of the multiple redox couples $\mathrm{Ni}^{2+} / \mathrm{Ni}^{3+}$, $\mathrm{Cr}^{2+} / \mathrm{Cr}^{3+}, \mathrm{Mn}^{2+} / \mathrm{Mn}^{3+}$, and the oxygen-vacant sites affect the acid/base properties of derived mixed oxides. This dual functionality is of crucial importance for the process selectivity towards bio-DEE and bio-butanol. This complex issue is currently under detailed investigation by our group.

\subsection{Structural Changes of Catalyst}

The average Raman spectra of WP1 before and after the reaction are present in Figure 7A,B, respectively. The spectrum of the sample before the reaction displays bands at $391 \mathrm{~cm}^{-1}$, originating from the $\mathrm{A}_{1}$ phonon mode of $\mathrm{Al}^{3+}$ or $\mathrm{Ni}^{2+}$ species, at $562 \mathrm{~cm}^{-1}$, ascribed to phonon mode of $\mathrm{Ni}^{2+}$ species, at $816 \mathrm{~cm}^{-1}$, corresponding to the condensed tetrahedral $\mathrm{AlO}_{4}$, at $1104 \mathrm{~cm}^{-1}$, assigned to $\mathrm{vCO}_{3}{ }^{2-}$ ion, and at $1605 \mathrm{~cm}^{-1}$, from an unknown source [1-4]. 

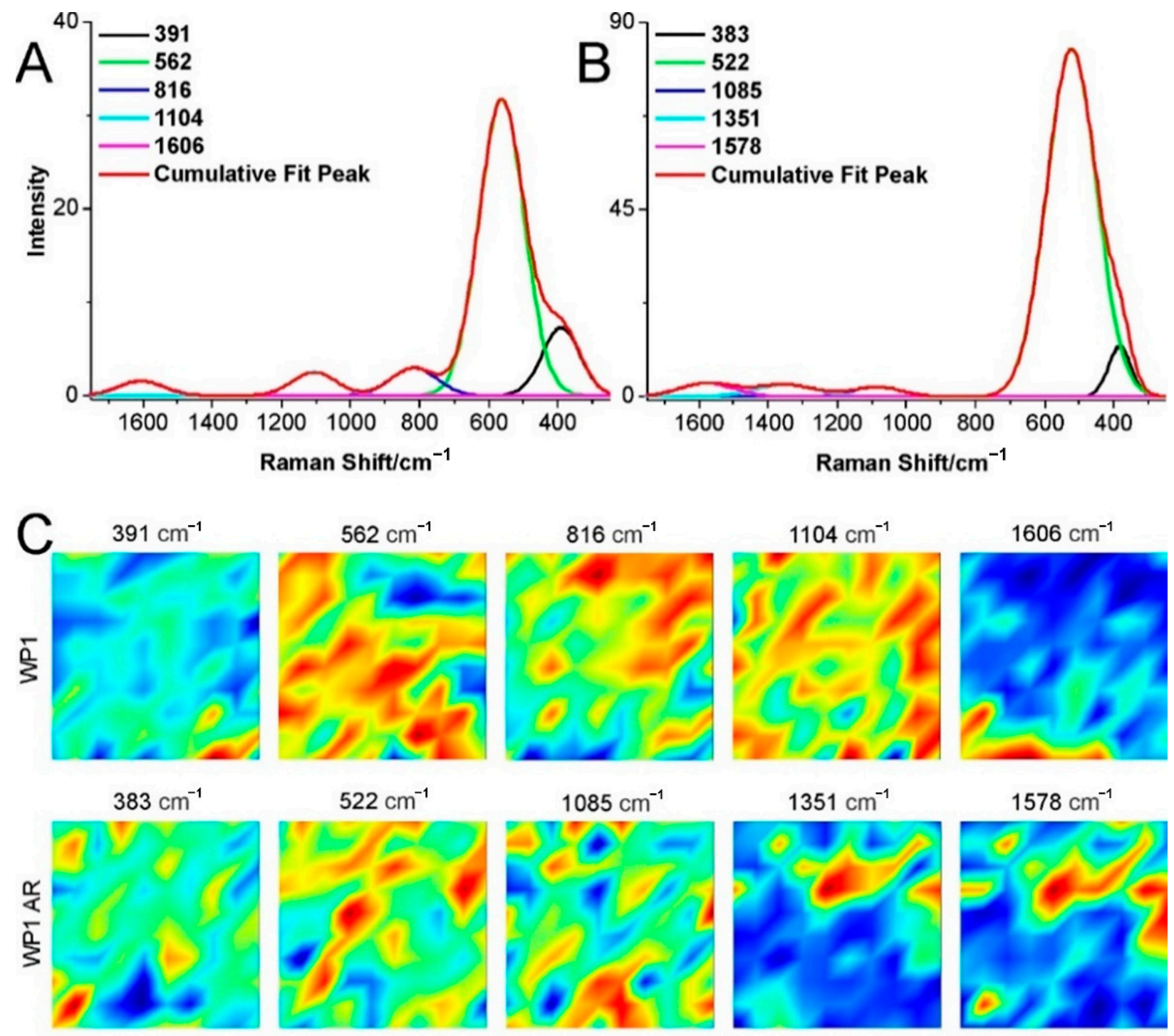

Low

Intensity

High

Figure 7. Deconvoluted Raman spectra of the WP1 (A) before and (B) after the reaction. (C) Raman maps with the distribution of selected WP1 bands (top row) before and (bottom row) after the reaction. Red spectra correspond to the cumulative spectrum consisting of the deconvoluted bands. Other colors of spectra correspond to the single deconvoluted bands.

The spectrum of the after-reaction sample contains bands at $383 \mathrm{~cm}^{-1}$, corresponding to the $\mathrm{A}_{1}$ phonon mode of $\mathrm{Al}^{3+}$ or $\mathrm{Ni}^{2+}$ species, and at $522 \mathrm{~cm}^{-1}$, ascribed to the phonon mode of $\mathrm{Ni}^{2+}$ species. The band at $816 \mathrm{~cm}^{-1}$, corresponding to condensed tetrahedral $\mathrm{AlO}_{4}$, was present in the sample's spectrum before but not after the reaction. Moreover, the band at $1085 \mathrm{~cm}^{-1}$ appeared in the after-reaction sample. This band is ascribed to either two phonon modes of $\mathrm{Ni}^{2+}$ species or $\mathrm{vCO}_{3}{ }^{2-}$ ion [3]. The latter is more probable as a similar band was present in the sample's spectrum before reaction (at $1104 \mathrm{~cm}^{-1}$ ). Two additional bands, located at 1351 and $1578 \mathrm{~cm}^{-1}$, are present in the sample's spectrum after the reaction. They are assigned to imperfect graphite (D band) and perfect graphite or graphene ( $\mathrm{G}$ band), respectively [5]. Bands at $\sim 385$ and $\sim 540 \mathrm{~cm}^{-1}$ are present in both samples' spectra. However, both bands are significantly shifted toward lower Raman shift values in the after-reaction sample's spectrum compared to that of the before-reaction sample. This result suggests a change in the catalyst structure. The band at $\sim 385 \mathrm{~cm}^{-1}$ has a comparable area under the curve in both samples. However, in the after-reaction 
sample's spectrum, the band at $\sim 540 \mathrm{~cm}^{-1}$ has a three-fold higher area compared to that before the reaction. This result might indicate the condensed tetrahedral $\mathrm{AlO}_{4}$ (the band that disappeared in the after-reaction sample) transformation to octahedral $\mathrm{AlO}_{6}$, which might be found in the lower Raman Shift values [1]. The G and D bands were present in the after-reaction sample's spectrum, suggesting that the reaction product was a coke.

In the chemical maps of the before-reaction sample, all bands, except for the one at $1605 \mathrm{~cm}^{-1}$, were evenly distributed throughout the sample. The band at $1605 \mathrm{~cm}^{-1}$ was observed on the sample surface, whereas the band at $816 \mathrm{~cm}^{-1}$ was absent. This result might indicate an incomplete reaction while creating the catalyst or uneven reaction throughout the sample. In the after-reaction sample's chemical maps, the bands corresponding to the catalyst were evenly distributed throughout the sample. The D and G bands were located in the specific sample areas. They were not correlated with the catalyst band occurrence, which proves that the reaction was complete and the catalyst did not degrade during the catalytic reaction (which was also proven when taking into account the averaged spectra). Moreover, D and $\mathrm{G}$ bands were distributed in the same sample locations, proving that the production of imperfect and perfect graphite or graphene needs the same conditions.

The average Raman spectra of WP2 before and after the reaction are present in Figure $8 \mathrm{~A}, \mathrm{~B}$, respectively.
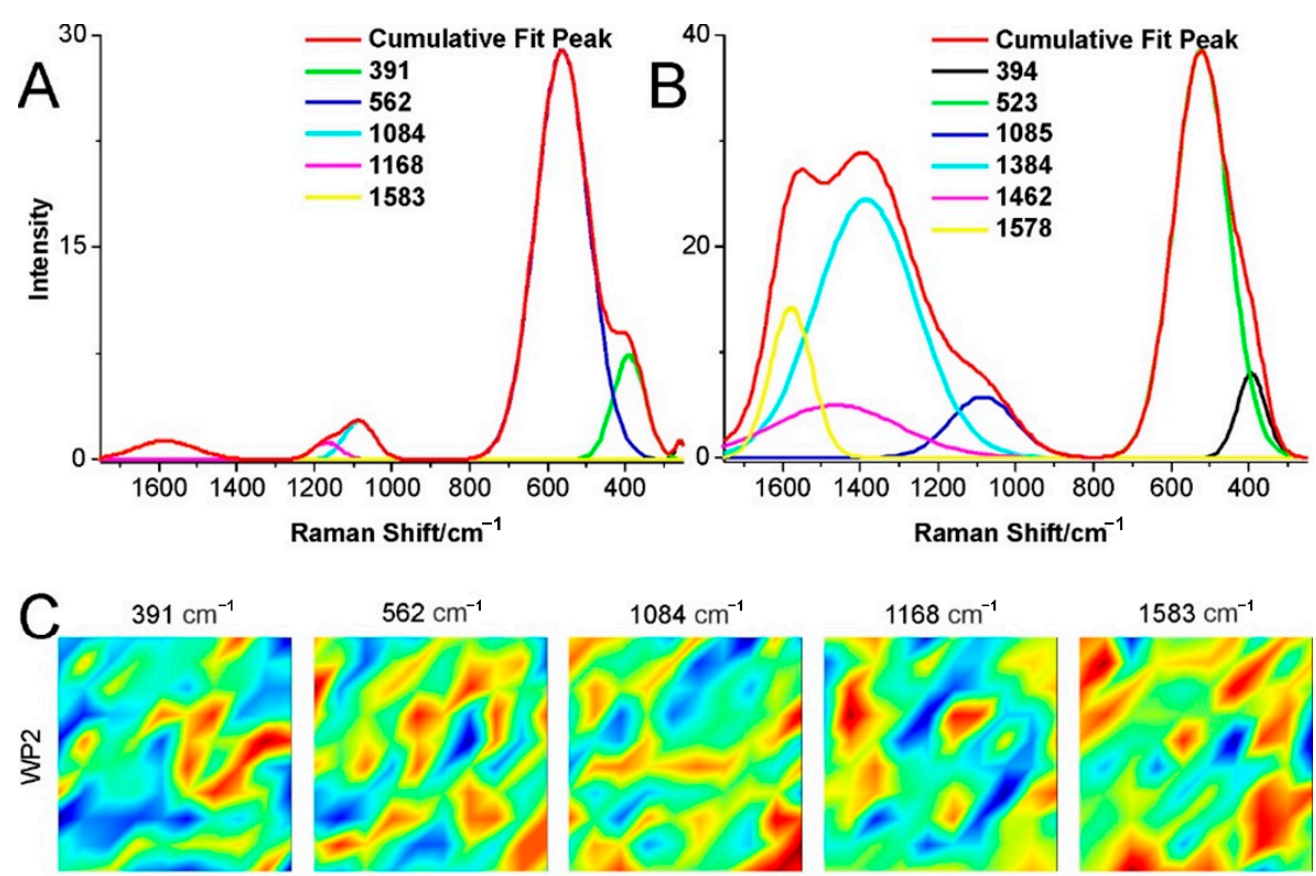

$562 \mathrm{~cm}^{-1}$

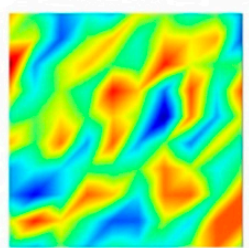

$1084 \mathrm{~cm}^{-1}$

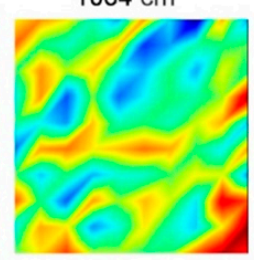

$1168 \mathrm{~cm}^{-1}$

$1583 \mathrm{~cm}^{-1}$
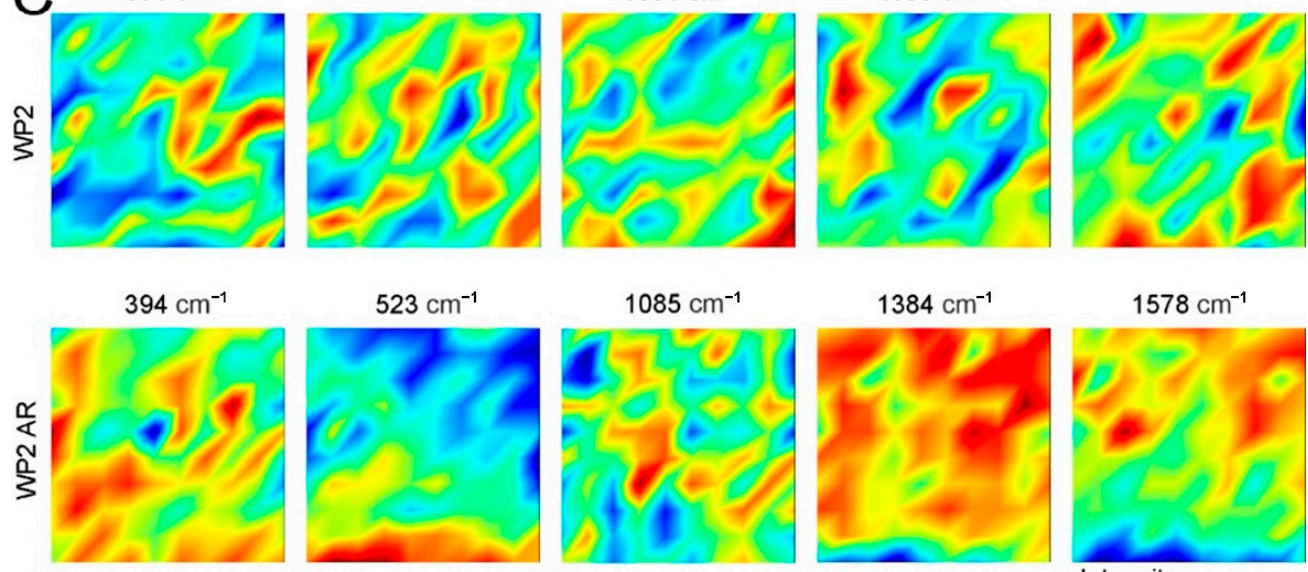

$1085 \mathrm{~cm}^{-1}$
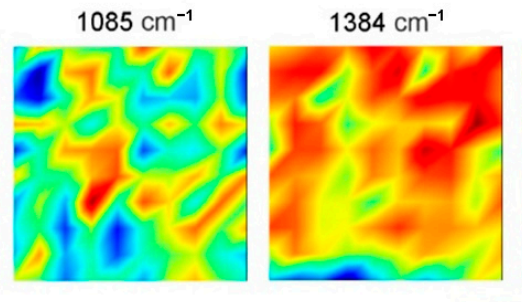

$1578 \mathrm{~cm}^{-1}$

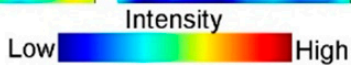

Figure 8. Deconvoluted Raman spectra of the WP2 (A) before and (B) after the reaction. (C) Raman maps with the distribution of selected WP2 bands (top row) before and (bottom row) after the reaction. Red spectra correspond to the cumulative spectrum consisting of the deconvoluted bands. Other colors of spectra correspond to the single deconvoluted bands. 
The WP2 spectrum displays bands at $391 \mathrm{~cm}^{-1}$, originating from the $\mathrm{A}_{1}$ phonon mode of $\mathrm{Al}^{3+}$ or $\mathrm{Ni}^{2+}$ species, at $562 \mathrm{~cm}^{-1}$, ascribed to the phonon mode of $\mathrm{Ni}^{2+}$ species, at $1084 \mathrm{~cm}^{-1}$, corresponding to either the two phonon modes of $\mathrm{Ni}^{2+}$ species or $\mathrm{VCO}_{3}{ }^{2-}$ ion, at $1168 \mathrm{~cm}^{-1}$, from an unknown source, and at $1583 \mathrm{~cm}^{-1}$, assigned to the $\mathrm{MgO}$ crystal G band $[2-4,6]$.

In the after-reaction sample, the spectrum contains bands at $394 \mathrm{~cm}^{-1}$, corresponding to the $\mathrm{A}_{1}$ phonon mode of $\mathrm{Al}^{3+}$ or $\mathrm{Ni}^{2+}$ species, at $523 \mathrm{~cm}^{-1}$, ascribed to the phonon mode of $\mathrm{Ni}^{2+}$ species, at $1085 \mathrm{~cm}^{-1}$, assigned to either the two phonon modes of $\mathrm{Ni}^{2+}$ species or $v \mathrm{CO}_{3}{ }^{2-}$ ion, at $1384 \mathrm{~cm}^{-1}$, ascribed to the imperfect graphite (D band), and at $1578 \mathrm{~cm}^{-1}$ correspond to perfect graphite or graphene ( $\mathrm{G}$ band) [5]. In the after-reaction sample, the band corresponding to the phonon mode of $\mathrm{Ni}^{2+}$ species was significantly shifted toward a lower Raman shift value. It is probably due to the slight change in the catalyst structure. The band at $1168 \mathrm{~cm}^{-1}$ was not detected in the after-reaction sample; however, it might be overlapped by D and G bands. Moreover, in the after-reaction sample's spectrum, D and G bands were present. Although the $\mathrm{G}$ band was also present in the before-reaction sample's spectrum, the $G$ band area in the after-reaction sample's spectrum was almost 7.5 times higher than that in the sample's spectrum before the reaction (1899 vs. 254), as visible in Figure $8 \mathrm{~A}, \mathrm{~B}$. This result shows that the sample induced coke production with very high abundance (higher than WP1).

Before the reaction, the chemical maps of the sample show that all catalyst bands were evenly distributed throughout the sample, proving the catalyst's chemical homogeneity. In the after-reaction sample, the chemical maps indicate that the intensity of the highest catalyst band (at $523 \mathrm{~cm}^{-1}$ ) was reversely proportional to the D and $\mathrm{G}$ bands. This result might suggest that the reaction was not complete and that the catalyst degraded as the reaction progressed. However, the latter is not true. The area of the band at $523 \mathrm{~cm}^{-1}$ in the after-reaction sample's spectrum was higher compared to that in the beforereaction sample's spectrum. The arguments mentioned above prove that the WP2 catalyst induced the coke production reaction with very high abundance and was stable in the used reaction conditions.

The average Raman spectra of WP4 before and after the reaction are present in Figure 9A,B, respectively.

The average spectrum of the sample before the reaction contains bands at $395 \mathrm{~cm}^{-1}$, corresponding to the $\mathrm{A}_{1}$ phonon mode of $\mathrm{Al}^{3+}$ or $\mathrm{Ni}^{2+}$ species, at $561 \mathrm{~cm}^{-1}$, ascribed to the phonon mode of $\mathrm{Ni}^{2+}$ species, at $804 \mathrm{~cm}^{-1}$, corresponding to the condensed tetrahedral $\mathrm{AlO}_{4}$, at $1084 \mathrm{~cm}^{-1}$, ascribed to either two phonon modes of $\mathrm{Ni}^{2+}$ species or $\mathrm{VCO}_{3}{ }^{2-}$ ion, and at $1142 \mathrm{~cm}^{-1}$, from an unknown source [1-4].

The average spectrum of the after-reaction sample contains bands at $402 \mathrm{~cm}^{-1}$, corresponding to the $\mathrm{A}_{1}$ phonon mode of $\mathrm{Al}^{3+}$ or $\mathrm{Ni}^{2+}$ species, at $531 \mathrm{~cm}^{-1}$, ascribed to the phonon mode of $\mathrm{Ni}^{2+}$ species, at $787 \mathrm{~cm}^{-1}$, corresponding to the condensed tetrahedral $\mathrm{AlO}_{4}$, at1084 $\mathrm{cm}^{-1}$, ascribed to either the two phonon modes of $\mathrm{Ni}^{2+}$ species or $\mathrm{vCO}_{3}{ }^{2-}$ ion, and at 1345,1579 , and $1606 \mathrm{~cm}^{-1}$, corresponding to the imperfect graphite (D band), perfect graphite or graphene ( $G$ band), and imperfect graphite or disordered carbon ( $D^{\prime}$ band), respectively [5]. In the after-reaction sample's spectrum, the band at $531 \mathrm{~cm}^{-1}$ was significantly shifted towards lower Raman Shift values compared to that in the before-reaction sample's spectrum. This result could indicate slight changes in the catalyst structure. The band at $1142 \mathrm{~cm}^{-1}$, present in the before-reaction sample, was not present in the afterreaction sample, probably due to the degradation or structural change in the substance corresponding to that band. Moreover, in the after-reaction sample, the D, G, and D' bands' presence proves that this catalyst induced coke production but with very low efficiency (based on the bands' area analysis). 

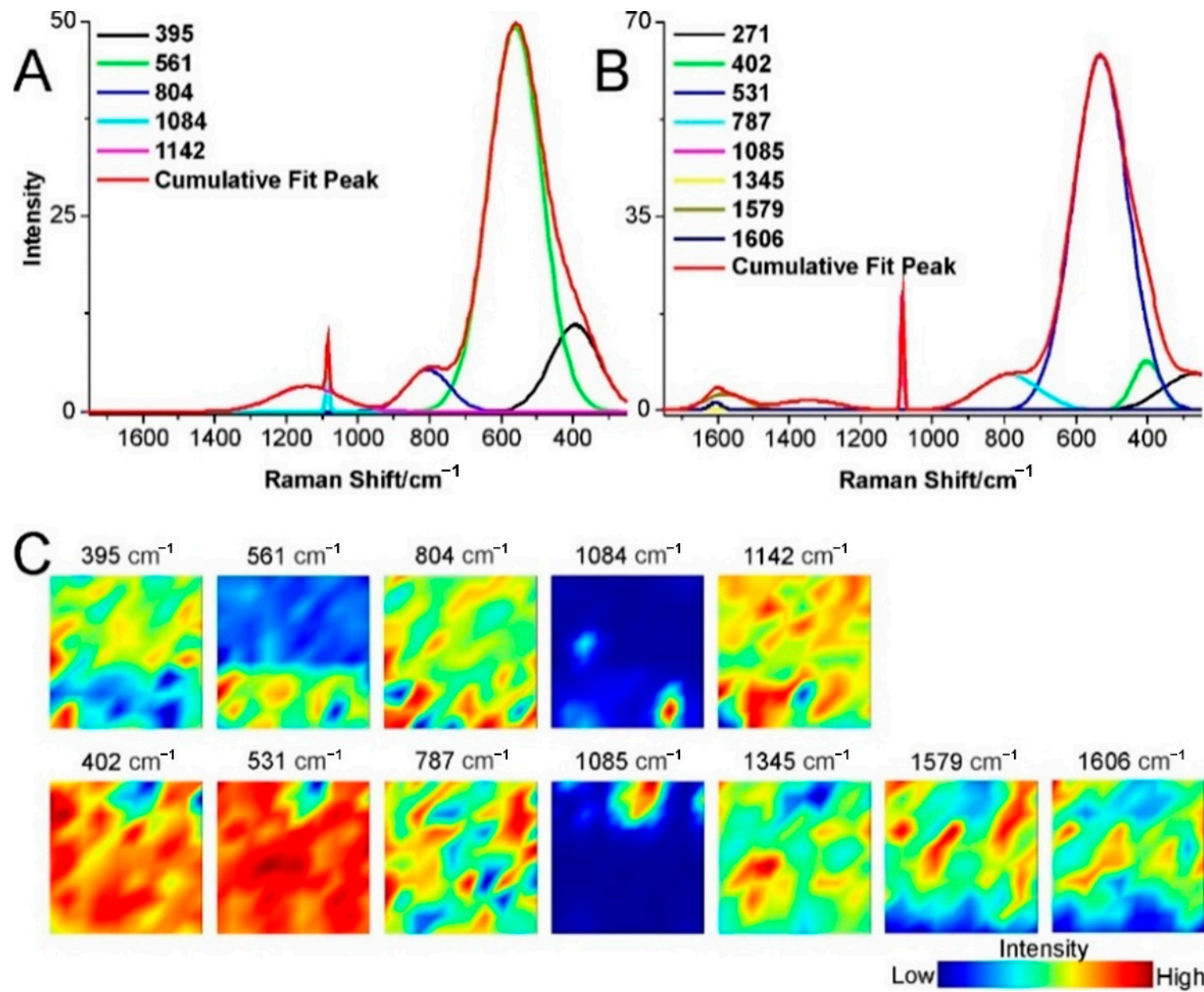

Figure 9. Deconvoluted Raman spectra of the WP4 (A) before and (B) after the reaction. (C) Raman maps with the distribution of selected WP4 bands (top row) before and (bottom row) after the reaction. Red spectra correspond to the cumulative spectrum consisting of the deconvoluted bands. Other colors of spectra correspond to the single deconvoluted bands.

The before-reactions sample's chemical maps consist of bands at 395, 804, and $1142 \mathrm{~cm}^{-1}$ that were evenly distributed throughout the sample. However, the band at $561 \mathrm{~cm}^{-1}$, the main band of the catalyst, and the band at $1084 \mathrm{~cm}^{-1}$ were distributed in specific sample regions, proving that the sample was not homogenous. In the after-reaction sample's chemical maps, all bands of the catalyst and its products were evenly distributed, except for the band at $1085 \mathrm{~cm}^{-1}$. This band's intensity was the highest in a specific sample spot. Moreover, the intensity of all other bands was low in the same spot (except for the band at $787 \mathrm{~cm}^{-1}$ ). These results indicate that the sample was not homogenous, and the spot with high intensity of $1085 \mathrm{~cm}^{-1}$ band had low catalytic efficiency.

\section{Materials and Methods}

\subsection{Materials and Reagents}

High purity Avantor Performance Materials $(\mathrm{POCH}$, Avantor Performance Materials Poland S.A., ul. Sowińskiego 11, Gliwice) nickel nitrate $\left(\mathrm{Ni}\left(\mathrm{NO}_{3}\right)_{2} \cdot 6 \mathrm{H}_{2} \mathrm{O}\right)$, magnesium nitrate $\left(\mathrm{Mg}\left(\mathrm{NO}_{3}\right)_{2} \cdot 6 \mathrm{H}_{2} \mathrm{O}\right)$, calcium nitrate $\left(\mathrm{Ca}\left(\mathrm{NO}_{3}\right)_{2} \cdot 4 \mathrm{H}_{2} \mathrm{O}\right)$, manganese nitrate $\left(\mathrm{Mn}\left(\mathrm{NO}_{3}\right)_{2} \cdot 4 \mathrm{H}_{2} \mathrm{O}\right)$, chromium nitrate $\left(\mathrm{Cr}\left(\mathrm{NO}_{3}\right)_{3} \cdot 9 \mathrm{H}_{2} \mathrm{O}\right)$, zirconium nitrate $\left(\mathrm{ZrO}\left(\mathrm{NO}_{3}\right)_{3} \cdot \mathrm{xH}_{2} \mathrm{O}\right)$, aluminum nitrate $\left(\mathrm{Al}\left(\mathrm{NO}_{3}\right)_{3} \cdot 9 \mathrm{H}_{2} \mathrm{O}\right)$, sodium hydroxide $(\mathrm{NaOH})$, sodium carbonate $\left(\mathrm{Na}_{2} \mathrm{CO}_{3}\right)$ and nitric acid $\left(\mathrm{HNO}_{3}\right)$ were used for the synthesis of the $\mathrm{LDH}$. 


\subsection{Synthesis and Characterization}

The Ni-containing hydrotalcite-like precursors were synthesized by a co-precipitation method from an aqueous solution of appropriate nitrate salts. During the synthesis, the samples were prepared and denoted as WP1-WP5, respectively, with full composition given in Table 1. An identical synthetic procedure was applied in all cases, e.g., the WP1 sample was synthesized as follows: $\mathrm{Ni}\left(\mathrm{NO}_{3}\right)_{2} \cdot 6 \mathrm{H}_{2} \mathrm{O}$, and $\mathrm{Al}\left(\mathrm{NO}_{3}\right)_{3} \cdot 9 \mathrm{H}_{2} \mathrm{O}$ were dissolved in deionized water $(135 \mathrm{~mL})$ at a molar ratio of $\mathrm{M}^{2+} / \mathrm{M}^{3+}$ of 0.35 . The metallic salt solution was added dropwise into $370 \mathrm{~mL}$ of $0.2 \mathrm{M} \mathrm{Na}_{2} \mathrm{CO}_{3}$ solution under vigorous stirring. During the synthesis process, the temperature was maintained at $328 \mathrm{~K}$, and $\mathrm{pH}$ was kept at 10 by simultaneous addition of $1 \mathrm{M} \mathrm{NaOH}$. The obtained products were collected by centrifugation, washed several times with distilled water, and dried at $323 \mathrm{~K}$ in air. Then, the dried solids were ground using an agate mortar. A similar procedure was used to obtain WP2-WP5 precursors. Finally, to prepare the mixed oxide materials, the hydrotalcite precursors were calcined in a muffle furnace at $823 \mathrm{~K}$ for $4 \mathrm{~h}$.

The crystalline phases of all the synthesized hydrotalcite-like materials and the calcined products were determined from their XRD patterns, recorded using an X'Pert PRO PANalytical B.V. The X-ray diffractometer used $\mathrm{Cu} \mathrm{K} \alpha$ radiation $(40 \mathrm{kV}, 30 \mathrm{~mA})$ of $0.154 \mathrm{~nm}$. The XRD data were collected between $2 \theta=2^{\circ}$ and $72^{\circ}$.

Raman spectra were collected in a Thermo Scientific DXR Raman Microscope, working at an exciter line of $532 \mathrm{~nm}$ and incorporating a Charge Couple Device (CCD) detector. Spectra were recorded in the $200-2000 \mathrm{~cm}^{-1}$ Raman shift range with an accumulation time of nearly $5 \mathrm{~s}, 10 \mathrm{~mW}$ of power, and 64 scans.

IR spectra of calcined samples were collected in a Nicolet iS50 FT-IR spectrometer. A built-in all reflective, mid- and far-IR diamond attenuated total reflectance (ATR) and diffuse reflectance (DRIFT) modules were used to record the IR spectra. Typically, 100 scans were collected at a resolution of $1 \mathrm{~cm}^{-1}$ and $2 \mathrm{~mW}$ of power.

SEM images were obtained using the field-emission scanning electron microscope (FESEM) FEI Nova NanoSEM 450 Series under vacuum ca. $10^{-6}$ mbar. The WP catalyst sample powders were deposited onto the standard SEM specimen stub for precise positioning under the electron column for imaging. SEM images were collected using the Through Lens Detector (TLD) of secondary electrons at the primary beam energy of $10 \mathrm{keV}$ and $4.8 \mathrm{~mm}$ working distance from the pole piece. All images were obtained at a long scan acquisition time $(20 \mu \sigma)$ of typically $30 \mathrm{~s}$ per image after choosing the inspection region. HRTEM TITAN 60-300 instrument with an X-FEG-type emission gun operating at $80 \mathrm{kV}$ was used to record TEM images. The microscope was equipped with a Cs image corrector and a STEM high-angle annular dark-field detector (HAADF); its point resolution is $0.06 \mathrm{~nm}$ in TEM mode.

\subsection{Catalytic Tests}

The ethanol coupling tests were performed in a tubular fixed-bed reactor $(5 \mathrm{~mm}$ external diameter) equipped with an online mass spectrometer (MS). Typically, $40 \mathrm{mg}$ of sieved catalyst (20-40 mesh) was loaded into the reactor, and the remaining was filled with quartz sand (20-40 mesh). Before the reaction, the catalyst was pre-treated in situ with $\mathrm{He}\left(50 \mathrm{~mL} \mathrm{~min}{ }^{-1}\right)$ at $773 \mathrm{~K}$ with a rate of $10 \mathrm{~K} \mathrm{~s}^{-1}$ for $3 \mathrm{~h}$. Ethanol vapor and He were mixed into the reaction system after the reactor was cooled to $523 \mathrm{~K}$. The gas flow was set to $60 \mathrm{~mL} \mathrm{~min}^{-1}$. Before the ethanol admission into the reaction system, ethanol was vaporized at $423 \mathrm{~K}$ in a vaporizing chamber. The chromatographically pure ethanol was pumped into the vaporizing chamber at $50 \mu \mathrm{L} \mathrm{min}^{-1}$ using a high-performance liquid chromatography pump. The pipeline behind the reactor was heated to keep it at $473 \mathrm{~K}$. The products were identified and analyzed by online MS (Hiden, HPR 60). The ethanol conversion and product selectivity were calculated as follows:

$$
\mathrm{X} \%=\frac{\mathrm{n}_{\text {in }}-\mathrm{n}_{\text {unreacted }}}{\mathrm{n}_{\text {in }}} \times 100 \%
$$




$$
\begin{gathered}
\mathrm{S} \%=\frac{\mathrm{C}_{\text {mol of specific product }}}{\mathrm{C}_{\text {mol of products }}} \times 100 \% \\
\mathrm{C}_{\text {balance }} \%=\frac{\mathrm{C}_{\text {mol of products }}}{\mathrm{C}_{\text {mol of conversed ethanol }}} \times 100 \% \\
\mathrm{~S}_{\text {dehydrogenation } \%}=100 \%-\mathrm{S}_{\mathrm{DEE}} \% \\
\mathrm{~S}_{\mathrm{C}-\mathrm{C} \text { coupling } \%} \% \sum \mathrm{S}_{\mathrm{C}_{4}-\mathrm{C}_{4+} \text { products }} \%
\end{gathered}
$$

where $n_{\text {in }}$ and $n_{\text {unreacted }}$ are the moles of initial and unreacted ethanol; $C_{\text {mol }}$ is the mole number of carbon in the products and conversed ethanol; $S$ is the selectivity for $\operatorname{DEE}(\mathrm{M} / \mathrm{z}=59,74)$, and $\mathrm{C}_{4}-\mathrm{C}_{4+}$ products, such as $\mathrm{n}$-butanol $(\mathrm{M} / \mathrm{z}=56)$, ethyl acetate $(\mathrm{M} / \mathrm{z}=61)$, butanal $(\mathrm{M} / \mathrm{z}=72)$, butyl acetate $(\mathrm{M} / \mathrm{z}=73)$, ethyl butyrate $(M / z=101)$, 2-ethyl-butanal $(M / z=100)$, hexanal $(M / z=82)$, $n$-hexanol $(M / z=69)$, butyl butyrate $(M / z=89)$, ethyl caproate $(M / z=99)$.

\subsection{Raman Spectroscopy}

The Raman spectra were collected using a confocal Thermo DXR Raman Microscope. The magnification of the objective was $50 \times$, and the laser with $532 \mathrm{~nm}$ wavelength and $8 \mathrm{~mW}$ of power was used. The parameters were optimized before the analysis. The aperture was $50 \mu \mathrm{m}$ pinhole, the exposure time was $4 \mathrm{~s}$, and the number of exposures for one spectrum was 20 . All the samples were measured in the range $250-2700 \mathrm{~cm}^{-1}$; however, only the $250-1750 \mathrm{~cm}^{-1}$ spectral region is shown. The whole map was $15 \times 15 \mu \mathrm{m}$, and it was made with a step size of $1.5 \mu \mathrm{m} / 1.5 \mu \mathrm{m}$ in the $\mathrm{x} / \mathrm{y}$ axis direction. The spectra analysis (baseline correction, deconvolution) was performed using Origin Pro Software (v. 9.1, OriginLab Corporation, Northampton, MA, USA, 2013). The band frequencies, used for spectral deconvolution, were determined from the second derivative spectra. The chemical map analysis was carried out in CytoSpec (v. 2.00.01). Maps were normalized and baseline-corrected before the analysis.

\section{Conclusions}

The catalysts obtained from hydrotalcite-containing precursors have demonstrated a moderate activity in the dehydrogenation coupling of bio-ethanol to produce more caloric bio-fuels, namely, DEE and n-butanol. It was shown that, at given reaction conditions $(623 \mathrm{~K}$ and $0.1 \mathrm{MPa})$, the highest conversion was obtained for the bare $\mathrm{Ni}_{0.35} \mathrm{Al}-\mathrm{CO}_{3}(\mathrm{WP}-1)$ sample. Most likely, the basic sites highly influence catalyst activity. For the $\mathrm{Ni}$ and $\mathrm{Mg}$ containing catalyst $\left(\mathrm{Ni}_{0.35} \mathrm{Mg}_{0.13} \mathrm{Al}-\mathrm{CO}_{3}, \mathrm{WP} 2\right)$, the ethanol dehydrogenation was carried out with the highest efficiency with the participation of $\mathrm{Ni}$ sites and aldol condensation promoted by acid-base cooperation. Further material modification with $\mathrm{Cr}, \mathrm{Zr}$, and $\mathrm{Mn}$ increased the redox and oxygen storage capacity (OSC), increasing the number of oxygen vacancies in the corresponding mixed oxide lattice. Thus, in the final WP-3 catalysts $\left(\mathrm{Ni}_{0.35} \mathrm{Mg}_{0.13} \mathrm{Mn}_{0.0018} \mathrm{Cr}_{0.0017} \mathrm{Zr}_{0.0054} \mathrm{Al}-\mathrm{CO}_{3}\right)$, the aldol condensation was limited as the acidity increased, and the reaction seemed to be preferential towards DEE formation. $\mathrm{Mg}$ exchange on Ca during the catalyst precursor synthesis resulted in derived mixed oxides, with different basicities and/or different basic strength distributions, affecting the overall bio-ethanol conversion and selectivity towards DEE and n-butanol. The effect of promoters on the Ni particles' stability and the electronic effect on $\mathrm{Ni}$ in the dehydrogenation coupling of $C_{1}-C_{2}$ bio-alcohols towards ethers and $n$-butanol is currently under detailed investigation under the Waste2Fuel project.

All studied catalysts demonstrated the ability to synthesize coke. The $\mathrm{Ni}_{0.35} \mathrm{Mg}_{0.13} \mathrm{Al}-$ $\mathrm{CO}_{3}$, catalyst (WP2) demonstrated the highest efficiency, while the $\mathrm{Ni}$ - and Ca-containing catalyst (WP4) sample's efficiency was the lowest. All samples' structures changed during the reaction; however, WP1 and WP2 probably did not degrade under the reaction conditions used. The WP4 sample' structure was inhomogeneous. 
Author Contributions: Conceptualization and project management, I.S.P.; methodology and software, A.M., A.S.-B., P.P., D.M., R.N., I.S.P., and E.M.S.; formal analysis, A.S.-B., P.P., D.M., R.N., I.S.P., A.L., and E.M.S.; investigation, I.S.P., A.L.G, M.K., A.S.-B., P.P, D.M., A.S., E.W., R.N., and E.M.S.; writing—original draft preparation, I.S.P., D.M., A.L.-G., and E.K.; writing—review and editing, I.S.P., A.L.-G., M.K., A.S.-B., P.P., D.M., R.N., and E.M.S.; visualization, I.S.P., A.L.-G., D.M., P.P., A.S.-B., and M.K.; funding acquisition, I.S.P. All authors have read and agreed to the published version of the manuscript.

Funding: The present research was financially supported by the Foundation for Polish Science, co-financed by the European Regional Development Fund under the Smart Growth Operational Programme PO IR, project no. REINTEGRATION/2016-1/5 Waste into fuel-catalyst and process development for waste biomass valorization, www.waste2fuel.edu.pl. I.S.P. and P.P. extend their sincere appreciation to NAWA The Polish National Agency for Academic Exchange through Bekker grants $\mathrm{PPN} / \mathrm{BEK} / 2019 / 1 / 00348$ " $\mathrm{C}_{1}-\mathrm{C}_{4}$ alkanes to oxygenated fuel electrochemical transformation" and $\mathrm{PPN} / \mathrm{BEK} / 2019 / 1 / 00345$ "Nanostructured carbon-based materials doped with metal nanoparticles as catalytic electrode materials for $\mathrm{CO}_{2}$ electroreduction with the use of surface-plasmon enhancement". The research activity of D.M. was supported by funds from the European Union's Horizon 2020 research and innovation program under the Marie Skłodowska-Curie grant agreement No. 711859 and by financial resources for science in the years 2017-2021 awarded by the Polish Ministry of Science and Higher Education for the implementation of an international co-financed project.

Conflicts of Interest: The authors declare no conflict of interest.

\section{References}

1. Houghton, J.T.; Jenkins, G.J.; Ephraums, J.J. Intergovernmental Panel on Climate Change; Cambridge University Press: Cambridge, UK, 1990; ISBN 978-0-521-40360-3.

2. Colmenares, J.C.; Colmenares Quintero, R.F.; Pieta, I.S. Catalytic Dry Reforming for Biomass-Based Fuels Processing: Progress and Future Perspectives. Energy Technol. 2016, 4, 881-890. [CrossRef]

3. Gawande, M.B.; Goswami, A.; Felpin, F.X.; Asefa, T.; Huang, X.; Silva, R.; Zou, X.; Zboril, R.; Varma, R.S. Cu and Cu-Based Nanoparticles: Synthesis and Applications in Catalysi. Chem. Rev. 2016, 116, 3722-3811. [CrossRef] [PubMed]

4. Goswami, A.; Rathi, A.K.; Aparicio, C.; Tomanec, O.; Petr, M.; Pocklanova, R.; Gawande, M.B.; Varma, R.S.; Zboril, R. In situ generation of Pd-Pt core-shell nanoparticles on reduced graphene oxide (Pd@ Pt/rGO) using microwaves: Applications in dehalogenation reactions and reduction of olefins. ACS Appl. Mater. Interfaces 2017, 9, 2815-2824. [CrossRef] [PubMed]

5. Lin, X.-X.; Wang, A.-J.; Fang, K.-M.; Yuan, J.; Feng, J.-J. One-Pot Seedless Aqueous Synthesis of Reduced Graphene Oxide (rGO)-Supported Core-Shell Pt@Pd Nanoflowers as Advanced Catalysts for Oxygen Reduction and Hydrogen Evolution. ACS Sustain. Chem. Eng. 2017, 5, 8675-8683. [CrossRef]

6. Gibson, G.; Winne, S.; Levin, S.; Skinner, I.; Tsamis, A.; Twisse, F.; Biedka, M.; Brannigan, C. Transport. State of the Art onAlternative FuelsTransport Systemsin the European Union; Update 2020; European Commission: Brussels, Belgium, 2020.

7. Aresta, M.; Dibenedetto, A.; Quaranta, E. State of the art and perspectives in catalytic processes for CO2 conversion into chemicals and fuels: The distinctive contribution of chemical catalysis and biotechnology. J. Catal. 2016, 343, 2-45. [CrossRef]

8. European Environment Agency. "Energy". Available online: https://www.eea.europa.eu/themes/energy/intro (accessed on 15 November 2020).

9. EU Agency, Transport Environment. Roadmap to De-Carbonising European Shipping. Available online: https://www. transportenvironment.org/sites/te/files/publications/2018_11_Roadmap_decarbonising_European_shipping.pdf (accessed on 15 November 2020).

10. Kowalik, P.; Antoniak-Jurak, K.; Błesznowski, M.; Herrera, M.C.; Larrubia, M.A.; Alemany, L.J.; Pieta, I.S. Biofuel steam reforming catalyst for fuel cell application. Catal. Today 2015, 254, 129. [CrossRef]

11. Zinoviev, S.; Müller-Langer, F.; Das, P.; Bertero, N.; Fornasiero, P.; Kaltschmitt, M.; Centi, G.; Miertus, S. Next-generation biofuels: Survey of emerging technologies and sustainability issues. ChemSusChem 2010, 3, 1106-1133. [CrossRef]

12. Pieta, I.S.; Epling, W.S.; Kazmierczuk, A.; Lisowski, P.; Nowakowski, R.; Serwicka, E. Waste into Fuel-Catalyst and Process Development for MSW Valorisation. Catalysts 2018, 8, 113-128. [CrossRef]

13. Agrafiotis, C.; Roeb, M.; Sattler, C. A review on solar thermal syngas production via redox pair-based water/carbon dioxide splitting thermochemical cycles. Renew. Sustain. Energy Rev. 2015, 42, 254-285. [CrossRef]

14. Rostrup-Nielsen, J. Syngas in Perspective. Catal. Today 2002, 71, 243-247. [CrossRef]

15. EU. Status Review of Renewable Support. Schemes in Europe for 2016 and 2017; Ref: C18-SD-63-0314; Council of European Energy Regulators: Brussels, Belgium, 2018.

16. Matsakas, L.; Gao, Q.; Jansson, S.; Rova, U.; Christakopoulos, P. Green conversion of municipal solid wastes into fuels and chemicals. Electron. J. Biotechnol. 2017, 26, 69-83. [CrossRef]

17. Chum, H.L.; Warner, E.; Seabra, J.E.A.; Macedo, I.C. A comparison of commercial ethanol production systems from Brazilian sugarcane and US corn. Biofuels Bioprod. Biorefining 2014, 8, 205-223. [CrossRef] 
18. Susmozas, A.; Martin-Sampedro, R.; Ibarra, D.; Eugenio, M.E.; Iglesias, R.; Manzanares, P.; Moreno, A.D. Process Strategies for the Transition of $1 G$ to Advanced Bioethanol Production. Processes 2020, 8, 1310. [CrossRef]

19. Kraleva, E.; Rodrigues, C.P.; Pohl, M.M.; Ehrich, H.; Noronh, F.B. Syngas production by partial oxidation of ethanol on PtNi/SiO2CeO2 catalysts. Catal. Sci. Technol. 2019, 9, 634. [CrossRef]

20. Kraleva, E.; Sokolov, S.; Schneider, M.; Ehrich, H. Support effects on the properties of Co and Ni catalysts for the hydrogen production from bio-ethanol partial oxidation. Int. J. Hydr. Energy 2013, 38, 4380-4388. [CrossRef]

21. Busic, A.; Mardetko, N.; Kundas, S.; Morzak, G.; Belskaya, H.; Ivancic Santek, M.; Komes, D.; Novak, S.; Santek, B. Bioethanol Production from Renewable Raw Materials and Its Separation and Purification: A Review. Food Technol Biotechnol. 2018, 56, 289-311. [CrossRef] [PubMed]

22. Karatzos, S.; McMillan, J.; Saddler, J. The Potential and Challenges of "Drop in" Biofuels International Energy Agency Bioenergy. Available online: http:/ / www.ieabioenergy.com/wp-content/uploads/2014/05/P02-The-potential-and-challenges-of-dropin-biofuels-Karatzos.pdf (accessed on 15 November 2020).

23. León, M.; Díaz, E.; Ordónez, S. Ethanol catalytic condensation over Mg-Al mixed oxides derived from hydrotalcites. Catal. Today 2011, 164, 436-442. [CrossRef]

24. Bravo-Suárez, J.J.; Subramaniam, B.; Chaudhari, V.R. Vapor-phase methanol and ethanol coupling reactions on CuMgAl mixed metal oxides. Appl. Catal. A 2013, 455, 234-246. [CrossRef]

25. Yang, C.; Meng, Z.Y. Bimolecular condensation of ethanol to 1-butanol catalyzed by Alkali Cation Zeolites. J. Catal. 1993, 142, 37-44. [CrossRef]

26. Ndou, A.S.; Plint, N.; Coville, N.J. Dimerisation of ethanol to butanol over solid-base catalysts. Appl. Catal. A 2003, 251, 337-345. [CrossRef]

27. Gautam, M.; Martin, D.W. Combustion characteristics of higher-alcohol/gasoline blends. Proc. Inst. Mech. Eng. 2000, $214,497-511$. [CrossRef]

28. Herman, R.G. Advances in catalytic synthesis and utilization of higher alcohols. Catal. Today 2000, 55, 233-245. [CrossRef]

29. Ndaba, B.; Chiyanzu, I.; Marx, S. n-Butanol derived from biochemical and chemical routes: A review. Biotechnol. Rep. 2015, 8, 1-9. [CrossRef] [PubMed]

30. Colley, S.W.; Fawcett, C.R.; Rathmell, C.; Tuck, M.W. Process for the Preparation of Ethylacetate. Patent USOO68092.17B1, 26 October 2004.

31. Matthey, J. Davy Technologies. Available online: http:/ / www.davyprotech.com/ (accessed on 15 November 2020).

32. Duan, X.; Evans, D.G. Layered Double Hydroxides; Springer: Berlin, Germany; New York, NY, USA, 2005.

33. Debek, R.; Zubek, K.; Motak, M.; Costa, P.D.; Grzybek, T. Effect of nickel incorporation into hydrotalcite-based catalyst systems for dry reforming of methane. Res. Chem. Intermed. 2015, 41, 9485-9495. [CrossRef]

34. Bhattacharyya, A.; Chang, V.W.; Schumacher, D.J. CO2 reforming of methane to syngas I: Evaluation of hydrotalcite clay-derived catalysts. Appl. Clay Sci. 1998, 13, 317-328. [CrossRef]

35. Koo, K.Y.; Lee, J.H.; Jung, U.H.; Kim, S.H.; Yoon, W.L. Combined H2O and CO2 reforming of coke oven gas over Ca-promoted $\mathrm{Ni} / \mathrm{MgAl} 2 \mathrm{O} 4$ catalyst for direct reduced iron production. Fuel 2015, 153, 303-309. [CrossRef]

36. Koo, K.Y.; Lee, S.H.; Jung, U.H.; Roh, H.S.; Yoon, W.L. Syngas production via combined steam and carbon dioxide reforming of methane over $\mathrm{Ni}-\mathrm{Ce} / \mathrm{MgAl} 2 \mathrm{O} 4$ catalysts with enhanced coke resistance. Fuel Process. Technol. 2014, 119, 151-157. [CrossRef]

37. Jang, W.-J.; Jeong, D.-W.; Shim, J.-O.; Kim, H.-M.; Roh, H.-S.; Son, I.H.; Lee, S.J. Combined steam and carbon dioxide reforming of methane and side reactions: Thermodynamic equilibrium analysis and experimental application. Appl. Energy 2016, 173, 80-91. [CrossRef]

38. Frost, R.L.; Palmer, S.J.; Theiss, F. Synthesis and Raman spectroscopic characterisation of hydrotalcites based on the formula Ca6Al2(CO3)(OH)16 4H2O. J. Raman Spectrosc. 2011, 42, 1163-1167. [CrossRef]

39. Jabbour, K.; Massiani, P.; Davidson, A.; Casale, S.; Hassan, N.E. Ordered mesoporous "one-pot" synthesized Ni-Mg(Ca)-Al2O3 as effective and remarkably stable catalysts for combined steam and dry reforming of methane (CSDRM). Appl. Catal. B Environ. 2017, 201, 527-542. [CrossRef]

40. Kong, X.; Zheng, R.; Zhu, Y.; Ding, G.; Zhu, Y.; Li, Y.W. Rational design of Ni-based catalysts derived from hydrotalcite for selective hydrogenation of 5-hydroxymethylfurfural. Green Chem. 2015, 17, 2504-2514. [CrossRef]

41. Lin, X.; Li, R.; Lu, M.; Chen, C.; Li, D.; Zhan, Y.; Jiang, L. Carbon dioxide reforming of methane over Ni catalysts prepared from Ni-Mg-Al layered double hydroxides: Influence of Ni loadings. Fuel 2015, 162, 271-280. [CrossRef]

42. Villegas, J.C.; Giraldo, O.H.; Laubernds, K.; Suib, S.L. New layered double hydroxides containing intercalated manganese oxide species: Synthesis and characterization. Inorg. Chem. 2003, 42, 5621-5631. [CrossRef] [PubMed]

43. Yu, X.; Wang, N.; Chu, W.; Liu, M. Carbon dioxide reforming of methane for syngas production over La-promoted NiMgAl catalysts derived from hydrotalcites. Chem. Eng. J. 2012, 209, 623-632. [CrossRef]

44. Zhang, J.; Zhao, N.; Wei, W.; Sun, Y. Partial oxidation of methane over Ni/Mg/Al/La mixed oxides prepared from layered double hydrotalcites. Int. J. Hydrog. Energy 2010, 35, 11776-11786. [CrossRef]

45. GSTC. Technology: Downstream Conversion Processes; Gasification \& Syngas Technologies Council: Arlington, VA, USA, 2016; Available online: http:/ / www.gasification-syngas.org/technology/downstream-conversion-processes/ (accessed on 15 November 2020). 
46. Hernández, W.Y.; Lauwaert, J.; van der Voort, P.; Verberckmoes, A. Recent advances on the utilization of layered double hydroxides (LDHs) and related heterogeneous catalysts in a lignocellulosic-feedstock biorefinery scheme. Green Chem. 2017, 19, 5269-5302. [CrossRef]

47. Serrano-Lotina, A.; Rodríguez, L.; Muñoz, G.; Martin, A.J.; Folgado, M.A.; Daza, L. Biogas reforming over La-NiMgAl catalysts derived from hydrotalcite-like structure: Influence of calcination temperature. Catal. Commun. 2011, 12, 961-967. [CrossRef]

48. Olszówka, J.E.; Karcz, R.; Michalik-Zym, A.; Napruszewska, B.D.; Bielańska, E.; Kryściak-Czerwenka, J.; Socha, R.P.; Nattich-Rak, M.; Krzan, M.; Klimek, A.; et al. Effect of grinding on the physico-chemical properties of Mg-Al hydrotalcite and its performance as a catalyst for Baeyer-Villiger oxidation of cyclohexanone. Catal. Today 2019, 33, 147-153. [CrossRef]

49. Michalik, A.; Napruszewska, B.D.; Walczyk, A.; Krysciak-Czerwenka, J.; Duraczynska, D.; Serwicka, E.M. Synthesis of Nanocrystalline Mg-Al Hydrotalcites in the Presence of Starch-the Effect on Structure and Composition. Materials 2020, 13, 602. [CrossRef]

50. Napruszewska, B.D.; Michalik-Zym, A.; Dula, R.; Bielanska, E.; Rojek, W.; Machej, T.; Socha, R.P.; Litynska-Dobrzynska, L.; Bahranowski, K.; Serwicka, E.M. Composites derived from exfoliated Laponite and Mn-Al hydrotalcite prepared in inverse microemulsion: A new strategy for design of robust VOCs combustion catalysts. Appl. Cat. B 2017, 211, 46-56. [CrossRef]

51. Napruszewska, B.D.; Michalik-Zym, A.; Dula, R.; Duraczyńska, D.; Rojek, W.; Socha, W.; Lityńska-Dobrzyńska, L.; Bahranowski, K.; Serwicka, E.M. VOCs combustion catalysts based on composites of exfoliated organo-Laponite and multimetallic (Mn, $\mathrm{Al}, \mathrm{Zr}$, Ce) hydrotalcites prepared by inverse microemulsion. Catal. Today 2019, 333, 182-189. [CrossRef]

52. Yamaguchi, K.; Ebitani, K.; Yoshida, T.; Yoshida, H.; Kaneda, K. Mg-Al Mixed Oxides as Highly Active Acid-BaseCatalysts for Cycloaddition of Carbon Dioxide to Epoxides. J. Am. Chem. Soc. 1999, 121, 4526-4527. [CrossRef]

53. Costantino, U.; Marmottini, F.; Nocchetti, M.; Vivani, R. New Synthetic Routes to Hydrotalcite-Like Compounds- Characterisation and Properties of the Obtained Materials. Eur. J. Inorg. Chem. 1998, 10, 1439-1446. [CrossRef]

54. Galvita, V.; Siddiqi, G.; Sun, P.; Bell, A.T. Ethane dehydrogenation on Pt/Mg(Al)O and PtSn/Mg(Al)O catalysts. J. Catal. 2010, 271, 209-219. [CrossRef]

55. Cavani, F.; Trifiro, F.; Vaccari, A. Hydrotalcite-type anionic clays: Preparation, properties and applications. Catal. Today 1991, 11, 173-301. [CrossRef]

56. NIST. Available online: https://www.nist.gov/pml/productsservices/physical-reference-data (accessed on 17 November 2020).

57. Konopacka-Łyskawa, D. Synthesis Methods and Favorable Conditions forSpherical Vaterite Precipitation: A Review. Crystals 2019, 9, 223-239. [CrossRef]

58. Popescu, M.A.; Isopescu, R.; Matei, C.; Fagarasan, G.; Plesu, V. Thermal decomposition of calcium carbonate polymorphs precipitatedin the presence of ammonia and alkylamines. Adv. Powder Technol. 2015, 25, 500-507. [CrossRef]

59. 'Cabrera, M.M.; Granados, M.L.; Fierro, J.L.G. Thermal decomposition of a hydrotalcite-containing Cu-Zn-Alprecursor: Thermal methods combined with anin situDRIFT study. Phys. Chem. Chem. Phys. 2002, 4, 3122-3127. [CrossRef]

60. Turco, M.; Bagnasco, G.; Costantino, U.; Marmottini, F.; Montanari, T.; Ramis, G.; Buscac, G. Production of hydrogen from oxidative steam reforming of methanol I. Preparation and characterization of $\mathrm{Cu} / \mathrm{ZnO} / \mathrm{Al} 2 \mathrm{O} 3$ catalysts from a hydrotalcite-like LDH precursor. J. Catal. 2004, 228, 43-55. [CrossRef]

61. Rives, V.; Kannan, S. Layered double hydroxides with the hydrotalcite-type structurecontaining Cu2z, Ni2z and Al3z J. Mater. Chem. 2000, 10, 489-495. [CrossRef]

62. Tamri, S.; Sta, I.; Jlassi, M.; Hajji, M.; Ezzaouia, H. Fabrication of ZnO-NiO nanocomposite thin films and experimental study of the effect of the $\mathrm{NiO}, \mathrm{ZnO}$ concentration on its physical properties. Mat. Sci. Semicond. Process. 2017, 71, 310-320. [CrossRef]

63. Wang, W.; Liu, Y.; Xua, C.; Zheng, C.; Wang, G. Synthesis of NiOnanorods by a novel simple precursor thermal decomposition approach. Chem. Phys. Lett. 2002, 362, 119-122. [CrossRef]

64. Jang, M.; Yoon, M.; Lee, S.; Kim, H.; Onodera, A.; Kojima, S. A study on the Raman spectra of Al-doped and Ga-doped ZnO ceramics. Curr. Appl. Phys. 2009, 9, 651-657. [CrossRef]

65. Pieta, I.S.; Rathi, A.; Pieta, P.; Nowakowski, R.; Hołdynski, M.; Pisarek, M.; Kaminska, A.; Gawande, M.B.; Zboril, R. Electrocatalytic methanol oxidation over $\mathrm{Cu}, \mathrm{Ni}$ and bimetallic $\mathrm{Cu}-\mathrm{Ni}$ nanoparticles supported on graphitic carbon nitride. Appl. Catal. $B$ 2019, 244, 272-283. [CrossRef]

66. Lewalska-Graczyk, A.; Pieta, P.; Garbarino, G.; Busca, G.; Holdynski, M.; Kalisz, G.; Sroka-Bartnicka, A.; Nowakowski, R.; Naushad, M.; Gawande, M.B.; et al. Graphitic Carbon Nitride-Nickel Catalyst: From Material Characterization to Efficient Ethanol Electrooxidation. ACS Sustain. Chem. Eng. 2020, 18, 7244-7255. [CrossRef]

67. Kouketsu, Y.; Mizukami, T.; Mori, H.; Endo, S.; Aoya, M.; Hara, H.; Nakamura, D.; Wallis, A. A new approach to develop the Raman carbonaceous materialgeothermometer for low-grade metamorphism using peak width. Isl. Arc. 2014, 23, 33-50. [CrossRef]

68. di Cosimo, J.I.; Díez, V.K.; Xu, M.; Iglesia, E.; Apesteguía, C.R. Structure and surface and catalytic properties of Mg-Al basic oxides. J. Catal. 1998, 178, 499-510. [CrossRef]

69. Di Cosimo, J.I.; Apesteguía, C.R.; Ginés, M.J.L.; Iglesia, E. Structural requirements and reaction pathways in condensation reactions of alcohols on MgyAlOx catalysts. J. Catal. 2000, 190, 261-275. [CrossRef]

70. Gabriels, D.; Hernández, W.Y.; Sels, B.; van der Voort, P.; Verberckmoes, A. Review of catalytic systems and thermodynamics for the Guerbet condensation reaction and challenges for biomass valorization. Catal. Sci. Technol. 2015, 5, 3876-3902. [CrossRef]

71. Chistyakov, A.V.; Nikolaev, S.A.; Zharova, P.A.; Tsodikov, M.V.; Manenti, F. Linear $\alpha$-alcohols production from supercritical ethanol over Cu/Al2O3 catalyst. Energy 2019, 166, 569-576. [CrossRef] 
72. Gallo, J.M.R.; Bueno, J.M.C.; Schuchardt, U. Catalytic Transformations of Ethanol for Biorefineries. J. Braz. Chem. Soc. 2014, 25, 2229-2243. [CrossRef]

73. Hu, X.X.; Wang, G.; Qin, C.; Xie, X.; Zhang, C.; Xu, W.; Liu, Y. Ligandless nickel-catalyzed transfer hydrogenation of alkenes and alkynes using water as the hydrogen donor. Org. Chem. Front. 2019, 6, 2619-2623. [CrossRef]

74. Zhang, J.; Shi, K.; An, Z.; Zhu, Y.; Shu, X.; Song, H.; Xiang, X.; He, J. Acid-Base Promoted Dehydrogenation Coupling of Ethanol on Supported Ag Particles. Ind. Eng. Chem. Res. 2020, 59, 3342-3350. [CrossRef] 